\title{
Relationship of
}

Precambrian Quartzite-Schist

Sequence Along Coal Creek

to Idaho Springs Formation

Front Range, Colorado

By JOHN D. WELLS, DOUGLAS M. SHERIDAN, and ARDEN L. ALBEE

SHORTER CONTRIBUTIONS TO GENERAL GEOLOGY

GEOLOGICAL SURVEY PROFESSIONAL PAPER 454-O

Prepared partly on behalf of the

U.S. Atomic Energy Commission

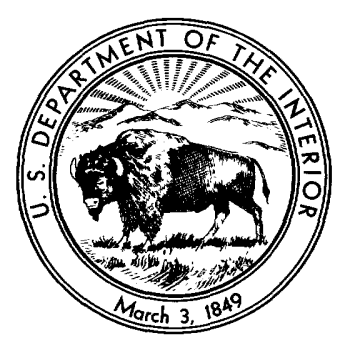

UNITED STATES GOVERNMENT PRINTING OFFICE, WASHINGTON : 1964 
UNITED STATES DEPARTMENT OF THE INTERIOR

STEWART L. UDALL, Secretary

GEOLOGICAL SURVEY

Thomas B. Nolan, Director

For sale by the Superintendent of Documents, U.S. Government Printing Office Washington, D.C. 20402 


\section{CONTENTS}

Abstract

Introduction

Fieldwork and acknowledgments

Scope of report.

Geologic setting . .

General geology . . . . . . . . .

Nomenclature of Precambrian rocks _.............

Distribution and stratigraphy of the metasedimentary and metavolcanic(?) rocks

Metamorphic grade

Metasedimentary and metavolcanic(?) rocks.......

Microcline-quartz-plagioclase-biotite gneiss (microcline gneiss)

Hornblende gneiss .

Microcline - quartz - placioclase - biotite gaei and hornblende gneiss (microcline gneiss and hornblende gneiss)

Mica schist . . . . . . . . . . . . . . . . . . .

Biotite-quartz-plagioclase gneiss and mica schist (biotite gneiss and mica schist)

Quartzite.

\begin{tabular}{|c|c|c|}
\hline Page & Metamorphic grade-Continued & Page \\
\hline 01 & Metasedimentary, etc.-Continued & \\
\hline 1 & Schist layers in quartzite & 09 \\
\hline 2 & Calcium silicate rocks with schist in quartzite.-. & 11 \\
\hline 2 & Igneous rocks_ & 11 \\
\hline 2 & Boulder Creek Granite and the quartz monzo- & \\
\hline 2 & nite & 11 \\
\hline 2 & Boulder Creek Granite. & 12 \\
\hline \multirow[t]{2}{*}{4} & Quartz monzonite & 12 \\
\hline & Hornblende diorite and hornblendite $\ldots \ldots \ldots$ & 13 \\
\hline 4 & Pegmatite and aplite & 13 \\
\hline 5 & Cataclastic rocks & 14 \\
\hline \multirow[t]{2}{*}{5} & Augen gneiss & 14 \\
\hline & Cataclastic gneiss_. & 14 \\
\hline 5 & Structural geology & 14 \\
\hline \multirow[t]{3}{*}{6} & Structural features, & 14 \\
\hline & Three periods of deformation & 15 \\
\hline & Orientation of lineations & 16 \\
\hline 6 & Metamorphism related to structural and igneous & \\
\hline \multirow[t]{2}{*}{6} & history & 21 \\
\hline & 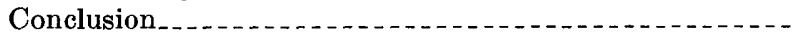 & 22 \\
\hline 7 & ture cited. & 22 \\
\hline 7 & Index & 25 \\
\hline
\end{tabular}

\section{ILLUSTRATIONS}

Plate 1. Geologic map of the Coal Creek area.

Page

In pocket

Figure 1. Index maps of the Coal Creek area, Eldorado Springs, Ralston Buttes, and Blackhawk quadrangles.......... O3

2. Photomicrograph showing staurolite surrounded by andalusite

3. Photomicrographs showing folded alinements in andalusite and cordierite

4. Triangular diagram of Boulder Creek Granite

5. Triangular diagram of the quartz monzonite

6. Hand specimen of quartzite

7. Index map showing location of sectors.

8. Contour diagrams of lineations

9. Contour diagrams of lineations

\section{TABLE}

TABLE 1. Nomenclature of Precambrian rocks, central Front Range 



\title{
RELATIONSHIP OF PREGAMBRIAN QUARTZITE-SGHIST SEQUENGE ALONG GOAL GREEK TO IDAHO SPRINGS FORMATION, FRONT RANGE, COLORADO
}

\author{
By John D. Wells, Douglas M. Sheridan, and Arden L. Albee
}

\begin{abstract}
The lithology, metamorphic grade, and structural history of the quartzite-schist sequence along Coal Creek 5 miles south of Boulder, Colo., are similar to these of the high-grade metamorphic gneisses of the Idaho Springs Formation elsewhere in the Front Range. Accordingly, the quartzite-schist sequence is to be regarded as a rather localized lithologic facies of the predominantly metasedimentary Idaho Springs Formation and not as a tectonically younger stratigraphic unit of lower metamorphic grade as previously described.

Four thick layers of quartzite and three of schist are preserved in the Coal Creek syncline-a major fold that plunges northeast. The quartzite contains sedimentary structures, is fine to coarse, light colored, locally conglomeratic, micaceous, and andalusite bearing. The schist layers consist mainly of muscovite, biotite, and quartz and contain andalusite, cordierite, and staurolite. South of the Coal Creek syncline are gneisses typical of the Idaho Springs Formation. These include feldspar, hornblende, and biotite gneisses and mica schist in an interlayered sequence characterized by gradational boundaries. Both the quartzite-schist sequence and the gneisses of typical Idaho Springs aspect have been intruded by the Boulder Creek Granite, and by quartz monzonite, hornblende diorite, horn-
\end{abstract} blendite, aplite, and pegmatite.

The quartzite-schist sequence and the typical gneisses of the Idaho Springs Formation are different in general aspect, but in detail each contains layers characteristic of the other, and the two sequences intergrade. The schist in the quartzite-schist sequence is virtually identical to schist that is interlayered with and grades into gneisses of the Idaho Springs Formation. Small pods of calcium silicate rock in the two sequences are identical.

The common occurrence of the critical muscovite-sillimanite suite in both the Idaho Springs gneisses and the quartzite-schist sequence, plus andalusite and cordierite in the latter, indicates metamorphism in the lower sillimanite zone. Locally the critical sillimanite-microcline suite is present in the gneisses; the presence indicates that the higher sillimanite zone was reached at least locally.

The metasedimentary rocks were deformed three times during Precambrian time. During the first period of deformation, a southwestward-plunging mineral lineation formed in the metasedimentary rocks. During the second period, the Coal Creek syncline formed. Lineations associated with this fold are present in the igneous rocks as well as in the metasedimentary rocks. During the third period, cataclastic deformation occurred along the Idaho Springs-Ralston shear zone south of the Coal Creek syncline, and distinctive cataclastic rock units were formed.

The Boulder Creek Granite was intruded syntectonically during the second period of deformation. It contains mineral lineations and minor folds like those in the Coal Creek syncline but contains no trace of lineations of the first deformation. The quartz monzonite was intruded soon after the Boulder Creek Granite and is closely associated with it; the hornblende diorite and hornblendite were probably intruded at nearly the same time. The aplite and pegmatite were intruded late in the Precambrian after the formation of the Idaho Springs-Ralston shear zone.

Three periods of metamorphism recognized in the quartziteschist sequence of the Coal Creek syncline are probably correlative with the three periods of structural deformation. The first period of metamorphism is represented by relict staurolite grains enclosed in andalusite grains. Relict microfolds, probably of the same age as the staurolite, are preserved in andalusite and cordierite grains. The second period of metamorphism is represented by the crystallization of andalusite and cordierite as well as other minerals of the high-grade rocks. This metamorphism took place during folding of the Coal Creek syncline and attendant igneous intrusion. The third period of metamorphism is represented by recrystallization during the cataclastic deformation. The cataclastic rocks contain highgrade metamorphic minerals such as sillimanite and show only slight evidence of retrograde metamorphism.

\section{INTRODUCTION}

The Precambrian metamorphic rocks in the Coal Creek area, near the mountain front between Boulder and the latitude of Denver, Colo., have been distinguished in the past from those of neighboring areas because they are of different character. They consist largely of quartzite and schist, whereas in nearby parts of the Front Range gneisses predominate that are generally assigned to the Idaho Springs Formation. The quartzite and schist, and minor accompanying rocks, form a thick sequence that appears more distinctly bedded and, at least superficially, less metamorphosed than the gneisses of the Idaho Springs Formation. For these reasons and also because it has been interpreted to be stratigraphically above the gneisses, the quartzite- 
schist sequence has been classed as a unit or formation distinctly younger than the Idaho Springs Formation (Marvine, 1874; Van Hise and Leith, 1909; Lovering, 1929 ; Lovering and Goddard, 1950).

Detailed studies leading to the present report have shown, however, that the quartzite-schist sequence has undergone exactly the same metamorphic, orogenic; and intrusive events as the gneisses assigned to the Idaho Springs Formation in neighboring areas. Further, schist that is virtually identical with that in the quartzite-schist sequence is intertongued with gneisses typical of the Idaho Springs Formation. Accordingly, the quartzite-schist sequence is to be regarded as a rather localized lithologic facies of the predominantly metasedimentary Idaho Springs Formation and not as a tectonically younger stratigraphic unit.

\section{LOCATION}

The boundaries of the Coal Creek area circumscribe the outcrops of the quartzite-schist sequence and adjacent parts of gneisses and schists of the Idaho Springs Formation and intrusive Precambrian igneous rocks. This area lies in Jefferson and Boulder Counties, Colo., just west of the upturned eastern flank of the Front Range about 20 miles northwest of Denver and 5 miles south of Boulder in the Ralston Buttes, Eldorado Springs, and Blackhawk quadrangles (fig. 1). South Boulder, Coal, and Ralston Creeks drain the area and have cut narrow steep-walled canyons $1,000-3,200$ feet deep in the flank of the range.

\section{FIELDWORK AND ACKNOWLEDGMENTS}

This report is the product of work done on two mapping projects, one in the Ralston Buttes quadrangle and the other in the Eldorado Springs quadrangle. The quartz-schist sequence characteristic of the Coal Creek area lies near the common boundary of the two quadrangles and is largely restricted to this area.

Mapping of Precambrian rocks in the Ralston Buttes quadrangle was begun in 1953 by $\mathrm{D}$. M. Sheridan and C. H. Maxwell on behalf of the Division of Raw Materials of the U.S. Atomic Energy Commission. This work continued intermittently until July 1956, with the aid of A. L. Albee after July 1955. Minor revisions were made by Sheridan in 1957 and 1958. Mapping of the Eldorado Springs quadrangle was begun by J. D. Wells in 1957, and the area included in this report was completed in 1958. A small area in the Blackhawk quadrangle was mapped by Sheridan, Wells, and C. T. Wrucke in 1958 to complete mapping of the area underlain by the quartzite.

The authors gratefully acknowledge the generous and courteous cooperation of the ranchers and property owners of the area, who without exception allowed access to their lands.

\section{SCOPE OF REPORT}

This report is restricted to the Precambrian geology of the quartzite-schist sequence along Coal Creek, as it is related to that of the Idaho Springs Formation nearby and elsewhere in the Front Range. Although the main topic of the report is the geology of the metasedimentary rocks, some discussion of accompanying igneous and cataclastic rocks is included for clarity.

The conclusions reached are based on three bodies of evidence. One relates to the lithologic similarities and stratigraphic relations between the quartzite-schist sequence and the typical gneisses of the Idaho Springs Formation. Another relates to similarities in metamorphism, as expressed by similarities in minerals, mineral suites, and rock textures. The third is structural and shows that these rocks have experienced the same intrusive and deformational events as the gneisses typical of the Idaho Springs rocks elsewhere in the Front Range.

\section{GEOLOGIC SETTING}

The Coal Creek area lies at the eastern edge of the Front Range-the easternmost range of the Southern Rocky Mountains. The range, which is $30-60$ miles wide and about 250 miles long, consists largely of Precambrian gneisses and schists and granitic intrusive rocks. These rocks are bordered by Paleozoic and Mesozoic sedimentary rocks that were upturned during the Laramide orogeny. Porphyritic igneous rocks were intruded and metalliferous deposits emplaced in the central part of the range during the orogeny.

The gneiss and schist consist of widespread biotitic, feldspathic, and hornblendic units that have been mapped as the Idaho Springs and Swandyke Formations (Spurr and others, 1908; and Lovering and Goddard, 1950). These rocks have been repeatedly deformed and now lie in a series of complex folds. Precambrian intrusive rocks are widespread in the range and consist of the Boulder Creek Granite, Silver Plume Granite, and Pikes Peak Granite, all of which occur as dikes, plutons, and batholiths.

\section{GENERAL GEOLOGY}

The Precambrian rocks of the Coal Creek area (pl. 1) consist of metamorphic rocks and intrusive igneous rocks (table 1) that were deformed by folding and cataclasis during Precambrian time. Pennsylvanian and younger sedimentary rocks overlie the Precambrian rocks on the eastern side of the area. Faulting and folding occurred during the Laramide mountain-building epoch. Quaternary alluvial and colluvial deposits 

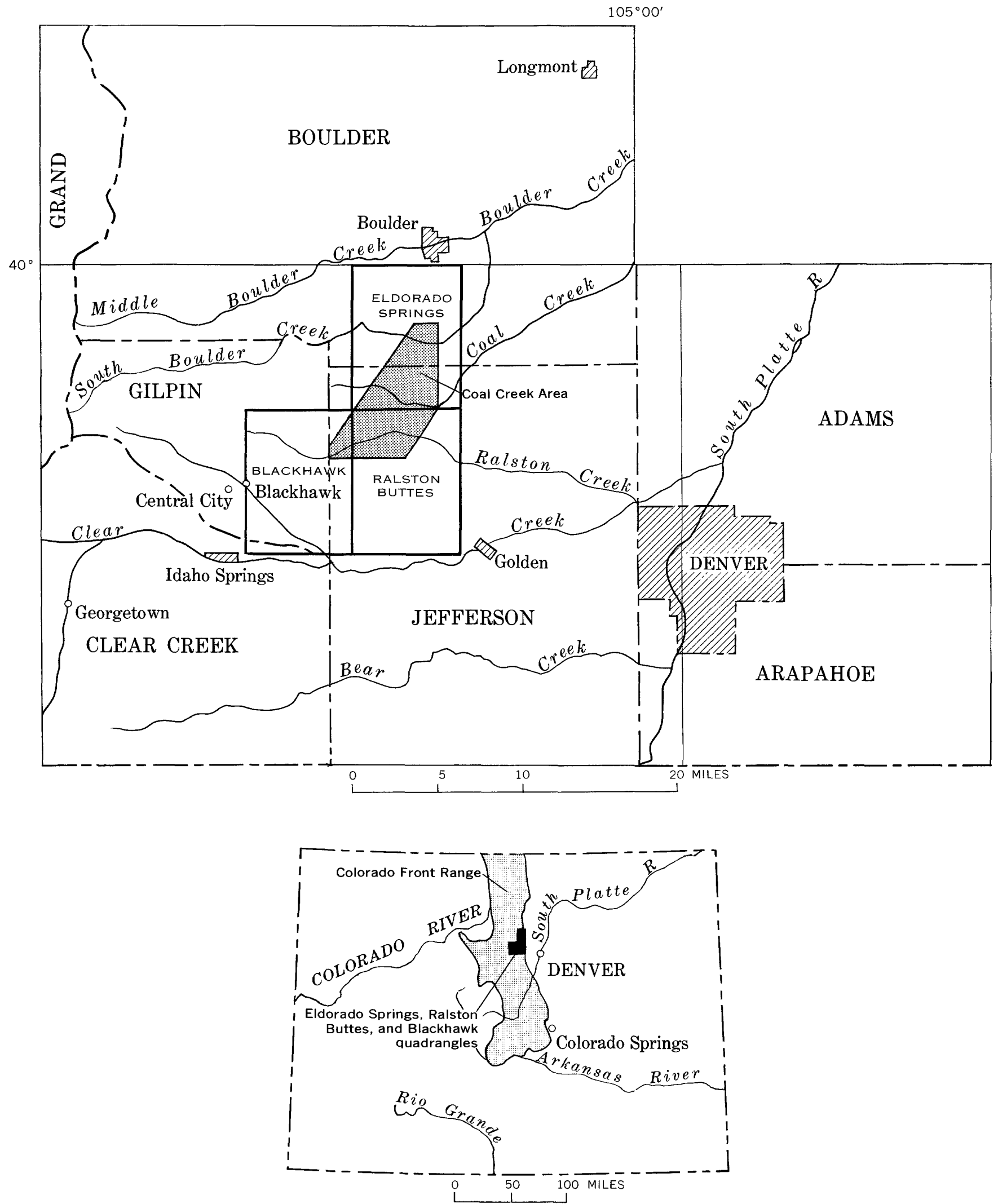

FIgURE 1.-Index maps showing location of the Coal Creek area in the Eldorado Springs, Ralston Buttes, and Blackhawk quadrangles in the Colorado Front Range. 
have accumulated in some of the valleys and cover some of the mountain sides.

The metamorphic rocks in the Coal Creek area are considered to be mostly metamorphosed sedimentary rocks, because of the variety of interlayered rock types with gradational boundaries and the relict sedimentary features displayed by the quartzite. Similar features have been pointed out and similar conclusions reached for these and other metamorphic rocks in the Front Range by earlier geologists (Spurr and others, 1908; Bastin and Hill, 1917; Lovering and Goddard, 1950; and Lovering and Tweto, 1953). Some of the amphibolite may represent metavolcanic rock derived from basic intrusive rocks or from volcanic debris.

The rocks are folded and generally well foliated and lineated. The foliation is shown by oriented platy minerals, color or compositional layering, and surfaces of cataclastic shear. The oriented minerals are almost always parallel to the layering. The rock units are arranged in a series of complex folds ranging in size from a mile wide or more to minute crinkles. The lineations are expressed by dimensional orientation of minerals, streaks caused by intracrystalline gliding, axes of folds, slickensides, and boudinage.

Cataclastic deformation has been intense in a zone along the south boundary of the quartzite (pl. 1). This is part of the Idaho Springs-Ralston shear zone ('Tweto and Sims, 1963). Original features of the metasedimentary rocks, and indeed, their identities, are difficult to determine in the zone of intense cataclasis.

The original sedimentary and volcanic(?) rocks were transformed to their present character during three recognized structural and metamorphic stages. The rocks were first subjected to plastic deformation and metamorphism in the low-alamandine amphibolite subfacies. A later deformation raised the metamorphic grade to the high-sillimanite subfacies and formed the Coal Creek syncline. It was accompanied by intrusion of Boulder Creek Granite, quartz monzonite, hornblende diorite, and hornblendite. In the third stage of Precambrian deformation, the Idaho Springs-Ralston shear zone was formed. The rocks in the shear zone were broken and recrystallized, but the metamorphic grade was lowered only locally. Pegmatite and aplite, probably associated with the intrusion of the Silver Plume Granite in nearby areas, was intruded as dikes and irregular bodies after the cataclasis.

\section{NOMENCLATURE OF PRECAMBRIAN ROCKS}

The rock units of this report are lithologic equivalents of units mapped in the Front Range mineral belt by Lovering and Goddard (1950) and in the Central City-Idaho Springs area by Bastin and Hill (1917),
Harrison and Wells (1956, 1959), Harrison and Moench (1961), and Young and Sims (1961). Various names were applied to the rock units in these reports. Since 1955 , names with mineral modifiers have been used, but these have gradually become long, confusingly numerous, and cumbersome. In the interests of brevity and readability, the names have been shortened in the text of this report, but they are mere abbreviations of the long or complete names, which are used in the headings and map explanation. Table 1 shows the names used in this report (the brief names are in parentheses) and the names given to equivalent units in earlier reports.

\section{DISTRIBUTION AND STRATIGRAPHY OF THE METASEDI- MENTARY AND METAVOLCANIC(?) ROCKS}

The metasedimentary and metavolcanic(?) rocks are in two lithologic and geographic groups. One, consisting largely of quartzite and schist, lies along the Coal Creek syncline; the other, consisting largely of feldspathic, hornblendic, and biotitic gneisses and mica schist, lies south of the syncline ( $\mathrm{pl} .1$ ).

The differences between the rocks of these two areas have been noted by many geologists and have been explained in various ways. The purpose here is not to emphasize the differences, but rather, to suggest that in many details the rocks of the two sequences are similar and that the sequences intergrade.

The units mapped to the south consist mainly of a conformable sequence of layers that vary widely in thickness, have gradational contacts, have various combinations of lithologies, and are of unknown relative age. The microcline gneiss unit consists mainly of feldspathic gneiss with characteristic thin layers of amphibolite. This unit has no counterpart along the Coal Creek syncline, although it is abundant in the Idaho Springs Formation in the central part of the Front Range. The hornblende gneiss unit consists largely of an intimately interlayered mixture of amphibolite and lesser amounts of biotite gneiss and calcium silicate rocks. These rocks are common elsewhere in the Front Range and they occur also in the schist along the syncline. The mica schist unit consists almost exclusively of muscovite-biotite schist with very minor amounts of rock gradational into biotite gneiss. The biotite gneiss and mica schist unit consists of an intimately interlayered mixture of these two rocks. The biotite gneiss is typical of the Idaho Springs Formation and the mica schist is very similar to the schist interlayered with quartzite along the Coal Creek syncline.

The quartzite-schist sequence along the Coal Creek syncline consists of a stratigraphic succession of four quartzite layers, mapped as a single unit, alternating with three schist layers, mapped as a unit. The age of 
PRECAMBRIAN QUARTZITE SCHIST, FRONT RANGE, COLO.

TABLE 1.-Nomenclature of Precambrian rocks of the central Front Range

[The arrangement of these units does not imply relative age]

\begin{tabular}{|c|c|c|c|c|c|}
\hline This report & $\begin{array}{l}\text { Lovering and Goddard } \\
\qquad(1950)\end{array}$ & $\begin{array}{l}\text { Harrison and Wells } \\
(1956 \text { and 1959) }\end{array}$ & $\underset{(1961)}{\text { Harrison and Moench }}$ & Ball (in Spurr, Garrey, and & Young and Sims (1961) \\
\hline $\begin{array}{l}\text { Microcline-quartz-plagioclase- } \\
\text { biotite gneiss (microcline } \\
\text { gneiss). }\end{array}$ & $\begin{array}{l}\text { Granite gneiss and gneissic } \\
\text { aplite. }\end{array}$ & Quartz monzonite gneiss.... & $\begin{array}{l}\text { Microcline-bearing } \\
\text { gneiss. }\end{array}$ & Probably gneissoid granite._. & $\begin{array}{l}\text { Microcline-quartz- } \\
\text { plagioclase-biotite } \\
\text { gneiss. }\end{array}$ \\
\hline $\begin{array}{l}\text { Microcline-quartz-plagioclase- } \\
\text { biotite gneiss and hornblende } \\
\text { gneiss (microcline gneiss and } \\
\text { hornblende gneiss). }\end{array}$ & $\begin{array}{c}\text { In part Swandyke horn- } \\
\text { blende gneiss, granite } \\
\text { gneiss, and gneissic aplite. }\end{array}$ & & & & \\
\hline Hornblende gneiss............ & $\begin{array}{l}\text { Swandyke hornblende } \\
\text { gneiss. }\end{array}$ & $\begin{array}{l}\text { Amphibolite, biotite-quartz } \\
\text { gneiss, biotite-quartz pla- } \\
\text { gioclase gneiss and cal- } \\
\text { cium-silicate gneiss. }\end{array}$ & -.. & $\begin{array}{l}\text { Hornblende gneiss and cal- } \\
\text { cium-silicate rocks. }\end{array}$ & Amphibolite. \\
\hline Mica schist........... & Idaho Springs formation & & & Idaho Springs formation. ... & \\
\hline $\begin{array}{l}\text { Biotite-quartz-plagioclase- } \\
\text { gneiss and mica schist (bio- } \\
\text { tite gneiss and mica schist). }\end{array}$ & Idaho Springs formation & $\begin{array}{l}\text { Biotite - quartz - plagioclase } \\
\text { and biotite-quartz gneiss. }\end{array}$ & $\begin{array}{l}\text { Interlayered biotite } \\
\text { gneisses. }\end{array}$ & Idaho Springs formation. & $\begin{array}{l}\text { Included in interlay- } \\
\text { ered biotite gneisses } \\
\text { and pegmatite. }\end{array}$ \\
\hline Quartzite & Quartzite at Coal Creek..... & & & & \\
\hline Sehist in quartzite & Schist layers in quartzite..-- & & & & \\
\hline $\begin{array}{l}\text { Augen gneiss and hornblende } \\
\text { gneiss. }\end{array}$ & $\begin{array}{l}\text { Included in the Idaho } \\
\text { Springs formation and } \\
\text { Swandyke hornblende } \\
\text { gneiss. }\end{array}$ & & & & \\
\hline \multicolumn{6}{|l|}{ Cataclastic gneiss } \\
\hline Boulder Creek Granite. & $\begin{array}{l}\text { Boulder Creek granite and } \\
\text { quartz monzonite. }\end{array}$ & Granodiorite & Granodiorite............ & Quartz monzonite & Granodiorite. \\
\hline Quartz monzonite.... & $\begin{array}{l}\text { Granite gneiss and gneissic } \\
\text { aplite. }\end{array}$ & & & & \\
\hline $\begin{array}{l}\text { Hornblende diorite and horn- } \\
\text { blendite. }\end{array}$ & $\begin{array}{l}\text { Quartz diorite and horn- } \\
\text { blendite. }\end{array}$ & $\begin{array}{l}\text { Quartz diorite and associ- } \\
\text { ated hornblendite. }\end{array}$ & $\begin{array}{l}\text { Quartz diorite and as- } \\
\text { sociated hornblend- } \\
\text { ite. }\end{array}$ & $\begin{array}{l}\text { Quartz-bearing_diorite and } \\
\text { associated horublendite. }\end{array}$ & \\
\hline Pegmatite and aplite............. & Pegmatite & Pegmatite.... & & Pegmatite..... & \\
\hline
\end{tabular}

these rocks relative to the gneisses to the south is unknown. The quartzite layers range from 400 to 3,600 feet in thickness. The schist layers are as much as 600 feet thick but in places are absent. The quartzite is micaceous, and the contacts between the quartzite and schist are gradational in most places. The quartzite has no known counterpart in the central Front Range. The schist, however, is almost identical to the mica schist that is interlayered with biotite gneiss south of the syncline.

A contact between the quartzite-schist sequence and the gneisses to the south exists for only about a mile in the canyon of lower Coal Creek; elsewhere, igneous rocks separate the two sequences. The contact has been blurred by cataclasis along the Idaho Springs-Ralston shear zone, and exposures along it are generally poor. The uncertainties of interpreting such a contact notwithstanding, the quartzite-schist sequence is believed to be a lithologic variant of the Idaho Springs Formation because (a) the calcium silicate rocks interlayered with the Idaho Springs Formation to the south are similar to those interlayered with the quartzite-schist sequence to the north; and (b) the schist to the south is identical to that interlayered with the quartzite and is interlayered with and grades into typical gneiss and schist of the Idaho Springs Formation.

\section{METAMORPHIC GRADE}

In the gneisses south of the Coal Creek syncline, the muscovite-sillimanite mineral suite is common, and the critical high-grade sillimanite-potassic feldspar suite (Heald, 1950; Thompson, 1957) is present. In the quartzite-schist sequence, muscoviate-sillimanite with andalusite and cordierite form the critical suite. Relict staurolite and microfolds indicate an earlier period of deformation by a somewhat lower grade of metamorphism.

In the Idaho Springs-Ralston shear zone the rocks are highly deformed mechanically and extensively recrystallized, but they show only slight retrograde metamorphism.

\section{METASEDIMENTARY AND METAVOLCANIC(?) ROCKS}

\section{MICROCLINE-QUARTZ-PLAGIOCLASE-BIOTITE GNEISS (MICROCLINE GNEISS)}

The microcline geniss unit trends westward across the southwestern part of the Coal Creek area (pl. 1). This unit lies between a thin belt of hornblende gneiss to the north and Boulder Creek Granite to the south. Microcline gneiss also occurs in the southeastern part of the Coal Creek area where it is complexly interlayered with other rocks; these interlayered rocks are described separately. 
Microcline gneiss is a fine- to medium-grained lightorange-pink, pinkish-gray, or dark-gray rock that consists mainly of microcline, quartz, plagioclase, and biotite. It is characterized by a granitic appearance and a conspicuous foliation shown by thin discontinuous aggregates of biotite having a preferred planar orientation and by biotite-rich and biotite-poor layers. Discontinuous conformable dark layers of amphibolite and biotite-quartz-plagioclase gneiss form a minor but constant part of the microcline gneiss in the Coal Creek area. "These minor rocks are similar in appearance and mineralogy to their counterparts in the hornblende gneiss unit.

The principal minerals of the gneiss (D. M. Sheridan, C. H. Maxwell, and A. L. Albee, unpublished data) are: Microcline 13-80 percent, quartz 14-54 percent, plagioclase (oligoclase-andesine) 1-26 percent, and biotite 4-18 percent. Accessory minerals include hornblende, apatite, magnetite-ilmenite, zircon, garnet, sphene, allanite, and minerals of the epidote group.

\section{HORNBLENDE GNEISS}

Two belts of hornblende gneiss lie adjacent to the mica schist in the southern part of the Coal Creek area, and a body that interfingers with the augen gneiss lies to the northeast (pl. 1). All of these thin westward, although their contacts with adjacent metasedimentary units appear to be conformable.

The hornblende gneiss is an interlayered sequence of gradational conformable layers of amphibolite, biotite gneiss, and intermediate rocks; calcium silicate gneiss, quartz gneiss, and impure marble are present locally. These layers are typically several feet to several tens of feet thick but locally are as much as 250 feet thick.

The amphibolite in the hornblende gneiss unit is dark gray to black and generally fine grained, although locally some is medium grained and has a spotted appearance. The amphibolite is composed mainly of equal amounts of hornblende and plagioclase (calcic oligoclase-sodic andesine) and small amounts of apatite, epidote, sphene, and opaque minerals (Sheridan and others, unpublished data).

The biotite gneiss is dark gray to black and generally fine grained. It consists primarily of quartz, plagioclase, and biotite; hornblende and microcline are minor constituents locally, and apatite, magnetite-ilmenite, zircon, allanite, epidote, and garnet occur in small amounts.

The calcium silicate rocks in the hornblende gneiss unit have a wide range in composition. The principal minerals are hornblende, plagioclase (andesine), quartz, and epidote, but microcline, clinopyroxene, garnet, magnetite-ilmenite, cummingtonite, tremolite, or calcite may predominate in individual layers. Accessory minerals present locally are sphene, apatite, tourmaline, scapolite, and vesuvianite. Locally the rock is rich in calcite and is better described as impure marble.

The quartz gneiss is fine-grained and predominantly gray but locally is white, black, or reddish gray in irregular color bands. It is composed predominantly of quartz but contains layers of magnetite-ilmenite, 1 $\mathrm{mm}$ to several centimeters thick and sporadic layers of garnet and hornblende.

\section{MICROCLINE-QUARTZ-PLAGIOCLASE-BIOTITE GNETSS AND HORNBLENDE GNEISS (MICROCLINE GNEISS AND HORNBLENDE GNEISS)}

The southeastern part of the Precambrian terrane in the Coal Creek area (pl. 1) is composed of microcline gneiss and hornblende gneiss in alternate layers a few inches to a few hundred feet thick. The intimate mixture of these rocks and their poor exposure preclude the possibility of mapping them individually at the scale used, and they are therefore mapped as a unit. The unit grades into the augen gneiss to the north. The two components of the unit are petrographically similar to the microcline and hornblende gneisses described previously, except that one specimen from the microcline gneiss contains abundant andalusite.

\section{MICA SCHIST}

The mica schist forms a generally eastward-trending tapering belt across the southern part of the area, south of Ralston Creek (pl. 1). This belt extends southeastward to the central and eastern part of the Ralston Buttes quadrangle where the outcrop width is about 3.5 miles in contrast to the 500-foot width near Ralston Creek. The unit is in transitional and conformable contact with hornblende gneiss throughout its extent in the area.

Most of the unit is a schist, although interlayered gneissic varieties are present near Ralston Creek. The schist is silvery gray to dark gray and fine to medium grained. It is composed of quartz, muscovite, and biotite in varying proportions and minor amounts of plagioclase and microcline. Glomeroporphyroblasts of sillimanite and porphyroblasts of andalusite and garnet are locally present, but they have not been found together in the same specimen. The microcline-sillimanite suite, indicating the high-sillimanite subfacies, was found in one specimen. The gneissic varieties are gradational with biotite gneiss; they contain significant amounts of plagioclase, are less well foliated than the schist, and take on the banded appearance of the biotite gneiss. Layers that range in thickness from fractions of an inch to several tens of feet differ in their proportions of quartz, muscovite, and biotite, and some contain concentrations of andalusite and garnet. 
Samples from the unit (Sheridan and others, unpublished data) contain from 45-79 percent quartz, trace amounts to 12 percent muscovite, 14-43 percent biotite and 0-20 percent plagioclase (oligoclase-andesine), 0-14 percent sillimanite, $0-1.3$ percent microcline, 0-1 percent garnet, and $0-25$ percent andalusite. Opaque minerals including magnetite, hematite, and leucoxene constitute as much as 1 percent, and tourmaline, apatite, and zircon occur in traces.

Muscovite and biotite occur in aggregates and as single crystals. The muscovite flakes cut through biotite crystals and are interlaminated with them, indicating a generally younger age for the muscovite, although both minerals have been deformed together.

Sillimanite, andalusite, and garnet are present in the schist units as porphyroblasts concentrated in the most micaceous varieties. Sillimanite glomeroporphyroblasts which consist of fine needles in elliptical aggregates $1 / 2-3 / 4$ of an inch long and in pencillike aggregates as much as 2 inches in length, are conspicuous in the central and southern parts of the Ralston Buttes quadrangle (Sheridan and others, unpublished data). Some of the sillimanite occurs as irregular aggregates interspersed with and replacing biotite; and sillimanite needles commonly penetrate quartz, muscovite, plagioclase, and microcline. Sillimanite has locally been partly or completely altered to fine-grained muscovite. Radially or diversely oriented blades of andalusite as much as 10 inches long lie in the plane of foliation in the central part of the Ralston Buttes quadrangle (Sheridan and others, unpublished data). In the Coal Creek area the andalusite contains poikiloblastic inclusions of quartz, biotite, and muscovite. Garnet porphyroblasts surrounded by quartz and containing poikilitic inclusions of quartz are locally present in the mica schist. South of the Coal Creek area the shape of certain aggregates of biotite and muscovite suggest pseudomorphs after staurolite, but no remnants of staurolite were found.

BIOTITE-QUARTZ-PLAGIOCLASE GNEISS AND MICA SCHIST (BIOTITE GNEISS AND MICA SCHIST)

The biotite gneiss and mica schist unit trends northeastward across the area from the southwest corner almost to Coal Creek (pl. 1). The northeastern part of the unit contains a central belt consisting of cataclastic gneiss. To the southwest, the unit thins and is cut out by intrusive igneous rocks.

The unit consists of gradational layers of biotite gneiss and mica schist ranging in thickness from a fraction of an inch to several feet. Locally thin layers of amphibolite and calcium silicate gneiss are interlayered with gneiss and schist. Some of the rock is intensely cataclasized in irregular poorly defined zones that are similar in appearance to the rock mapped as the cataclastic gneiss unit.

The biotite gneiss and mica schist is a gray to whiteand-gray layered well to poorly foliated rock consisting of quartz, muscovite, biotite, and plagioclase, and locally it contains potassic feldspar, sillimanite, and andalusite. In rocks that are predominantly schist, layering is shown by varying proportions of biotite, muscovite, quartz, and locally sillimanite; in the biotite gneiss, layering is expressed by the concentrations of biotite and of quartz and plagioclase. The potassic feldspar and sillimanite show metamorphism to be of the highsillimanite zone.

The mineral content (Sheridan and others, unpublished data) ranges from 30 to $\mathbf{7 1}$ percent quartz, trace quantities to 27 percent muscovite, 11-38 percent biotite, and 7-44 percent plagioclase. Potassic feldspar and sillimanite are not present in most specimens, but the rock contains as much as 9 percent microcline and 16 percent sillimanite. One specimen contains a trace of andalusite.

The muscovite commonly cuts across biotite grains. Both minerals show virtually the same degree of deformation, as indicated by folding and fragmentation. Sillimanite needles and aggregates cut through biotite, muscovite, potassic feldspar, and plagioclase. The sillimanite aggregates are commonly partly replaced by sericite. The extent of the deformation of the sillimanite is almost the same as in the other minerals. In the one occurrence of andalusite, the mineral is anhedral, as much as $1 \mathrm{~mm}$ in size and contains inclusions of quartz, muscovite, and opaque minerals.

\section{QUARTZITE}

Quartzite is exposed from Ralston Creek in the southwestern corner of the area to South Boulder Creek near Eldorado Springs in the northeastern corner (pl. 1). The quartzite is more resistant to erosion than any other unit in the area and forms the topographic highs of Blue and Crescent Mountains, and Coal Creek Peak. An almost complete section of it is exposed in the steep walls of the canyon of Coal Creek. The main mass of the quartzite lies in the Coal Creek syncline which has a northeastward-plunging axis extending 6 miles from Ralston Creek through Coal Creek Peak. Xenoliths of the quartzite lie in quartz monzonite and Boulder Creek Granite northwest of the main mass. In these xenoliths, foliations and lineations are parallel to those in the nearby main mass, and consequently they are probably roof pendants.

The quartzite unit consists of generally well foliated fine- to coarse-grained quartzite and interlayered conglomeratic quartzite. All of it is more or less micaceous. 
The mica flakes are generally oriented parallel to the compositional layers, although foliations crossing the layers are known. Bedding is expressed by variations in color, grain size, and mineral composition. The quartzite is white, pale red, gray, or black in layers a fraction of an inch to several hundred feet thick. When coarse grained, some of it is arkosic.

The conglomerate layers are discontinuous and range in thickness from less than a foot to several tens of feet. The boundaries are sharp, and no evidence of graded bedding was recognized. The pebbles are generally rounded and equidimensional to oval, although some are flat. Most of them are less than an inch across, but some are as much as several inches across. Most of the pebbles lie parallel to the bedding, although sparse groups of pebbles are inclined as much ds $20^{\circ}$ suggesting imbricate structure. The pebbles are almost exclusively quartzite; scarce pebbles of quartz-muscovite-magnetite schist have been found.

All the conglomerate and most of the quartzite observed is even bedded. In crossbedded layers noted locally, the bedding sets are lenticular, a few inches thick, only slightly curved, and transect other sets at angles generally less than $20^{\circ}$.

Four stratigraphic layers separated through most of their extent by layers of schist are recognized. From the lowest one upward, these are here referred to as layers $A, B, C$, and $D$. Layers $A$ and $B$ are generally white, light gray, or pink, fine grained to locally conglomeratic, and locally micaceous. Layer $C$ is generally gray and fine grained and has faint bedding; pink and white layers are also present. Almost all the specimens that contain andalusite are from this layer. Layer $D$ is white to pink; it contains abundant lenses of conglomerate, some of which are arkosic, but the quartzite between the lenses is fine grained.

The thickness of the quartzite layers varies from place to place. On the northern flank of the Coal Creek syncline, layer $A$ is at least 400 feet thick, and if the outliers to the northwest are included, it may be as much as 2,000 feet thick. Layer $B$ is about 1,800 feet thick on Blue Mountain but thins to about 500 feet south of the mountain. Layer $C$ is about 1,700 feet thick on Blue Mountain and 3,600 feet thick on Crescent Mountain, but only about 500 feet thick a mile southwest of Coal Creek Peak. Layer $D$ is nowhere exposed in its entirety, but about 2,000 feet of it is present on Coal Creek Peak.

Individual outcrops show the rocks in various structural aspects. Layers of massive quartzite commonly do not show small folds, but the micaceous varieties may show warps and open to tight folds. Folding is commonly disharmonic, and the micaceous layers are highly distorted. Locally, a crosscutting foliation formed parallel to the axial planes of tight drag folds as a result of shearing by overstretching during the folding. Where cataclastic zones cross the quartzite the effects range from minor breakage of mineral grains to development of catachlastic foliation planes that obliterate all older structures.

Most of the quartzite consists almost entirely of quartz and muscovite, but some beds contain local concentrations of andalusite, plagioclase, and microcline. Modal analyses (Sheridan and others, unpublished data) show the quantity of quartz to range from 56 to 93 percent and muscovite from a trace to 42 percent. Andalusite occurs principally in layer $C$ and constitutes 0-18 percent of the rock. A few specimens, all from layer $D$, contain feldspar-as much as 7 percent plagioclase and 3 percent microcline. A few specimens contain as much as 20 percent of chlorite and 38 percent of tourmaline, but these two minerals are generally absent or present only in traces. Opaque minerals are present in all specimens, in amounts ranging from a trace to 6 percent. Sillimanite, biotite, zircon, apatite, epidote, and sphene occur in trace quantities in some specimens.

The quartz grains in the quartzite are anhedral and irregular to equant. The equant grains are virtually undeformed. In the deformed rocks, the grains are strained and have irregular sutured boundaries. The boundaries of the pebbles are obscured by granulation but are faintly defined by opaque dust, mica, and andalusite in the cement of matrix. The fine grain of at least some of the quartzite is due to granulation.

Muscovite occurs in thin layers of flakes and books and as scattered flakes between and parallel to these layers. Most of the muscovite is clear but some contains minute opaque grains along cleavages. Much of it is shredded and bent, and in stringers along surfaces of intense shear it is very fine grained. Flakes of muscovite cut across, as well as replace, individual lamellae of the biotite. In some intensely deformed rocks, the muscovite is undeformed and has apparently recrystallized.

Plagioclase (oligoclase) and microcline occur as small anhedral broken and bent grains that are apparently detrital.

Andalusite occurs as scattered grains and layered concentrations and as granular aggregates, generally accompanied by opaque minerals. In conglomerate, it occurs as scattered fine grains between the pebbles. Poikiloblastic grains are uncommon in the quartzite, in contrast to the schist. Some shear surfaces wrap around andalusite grains and indicate that the andalusite was formed before the cataclasis.

Among the trace minerals, sillimanite occurs as radiating needles around muscovite grains in specimens containing andalusite. The tourmaline is black in hand 
specimen, but in thin section most of the crystals are yellow in the center and green on the margin. The chlorite is an alteration product of biotite. Magnetiteilmenite, hematite, and leucoxene occur in irregular aggregates, individual grains, and as dust. The dust and concentrations of the opaque minerals cause the gray coloring of many of the rocks.

\section{SCHIST LAYERS IN QUARTZITE}

Three major layers of schist alternate with the previously described four layers of quartzite along Coal Creek. The lower layer crops out in the southwestern part of the area (pl. 1) where it outlines the northeastward-plunging syncline. On the limbs of the syncline the layer thins and is cut off at a small angle by the intrusive quartz monzonite. The middle layer extends from about 1 mile southwest of Coal Creek Peak westward around Blue Mountain and pinches out on the north side of the mountain. It reappears along the northwest side of Crescent Mountain and extends northeastward to Eldorado Mountain, interrupted only by faults. The upper schist layer outlines the syncline around Coal Creek Peak and atop Blue Mountain. The schist layers are in gradational contact with those of quartzite, and the two lower layers contain many thin layers and lenses of quartzite.

The schist layers in the quartzite are in part fine grained and have been called phyllite (Lovering and Tweto, 1953, p. 8) as well as schist (Lovering and Goddard, 1950, p. 28). Part of the megascopically finegrained rock is phyllonite resulting from the breaking and shredding of mica flakes during cataclastic deformation. Other megascopically fine-grained rocks owe their apparent fineness of grain to very small scale crinkling that produces a sheen in reflected light that causes large mica flakes to appear much smaller. The general term, "fine-grained schist," will be applied to these rocks because not all of them are either phyllites or phyllonites and because the term "phyllite" may imply to some readers that low-grade rocks exist in the area, which is not true.

The schist is well foliated and generally contains a conspicuous mineral lineation. Crinkling of the foliation planes is common, and where intense there may be a slip cleavage parallel to the axial planes of the crinkles. Locally, the schist has been slightly to intensely deformed cataclastically.

The schist layers in quartzite consist predominantly of muscovite, biotite, and quartz, and there are local occurrences of andalusite, coriderite, garnet, plagioclase, sillimanite, and staurolite. (Sheridan and others, unpublished data.) Opague minerals are common and locally abundant. Muscovite and quartz are in all specimens, but the quantities range widely; muscovite ranges from 4 to 93 percent, and quartz ranges from a trace to 79 percent. Several specimens contain no biotite, although others contain as much as 43 percent. Andalusite is absent from the upper schist layer but is present in about half of the specimens from the middle and lower layers, where it makes up as much as 49 percent of the rock. Some specimens from the upper schist layer contain 3 percent plagioclase (oligoclase). Garnet is present in some specimens in amounts ranging from a trace to 10 percent, and cordierite is present in others, in amounts ranging from 1 to 8 percent. Sillimanite is found only in traces. Staurolite occurs sparsely in the middle schist layer. Opaque minerals constitute a trace to 16 percent of all the schist, and tourmaline, zircon, apatite, chlorite, and epidote occur as trace minerals.

Relict staurolite and microfolds visible in thin sections from the middle schist layer provide important data for interpretation of the metamorphic and structural history of this area. The staurolite ${ }^{1}$ occurs only as inclusions in andalusite, where it forms irregular grains with rounded corners (fig. 2). The staurolite

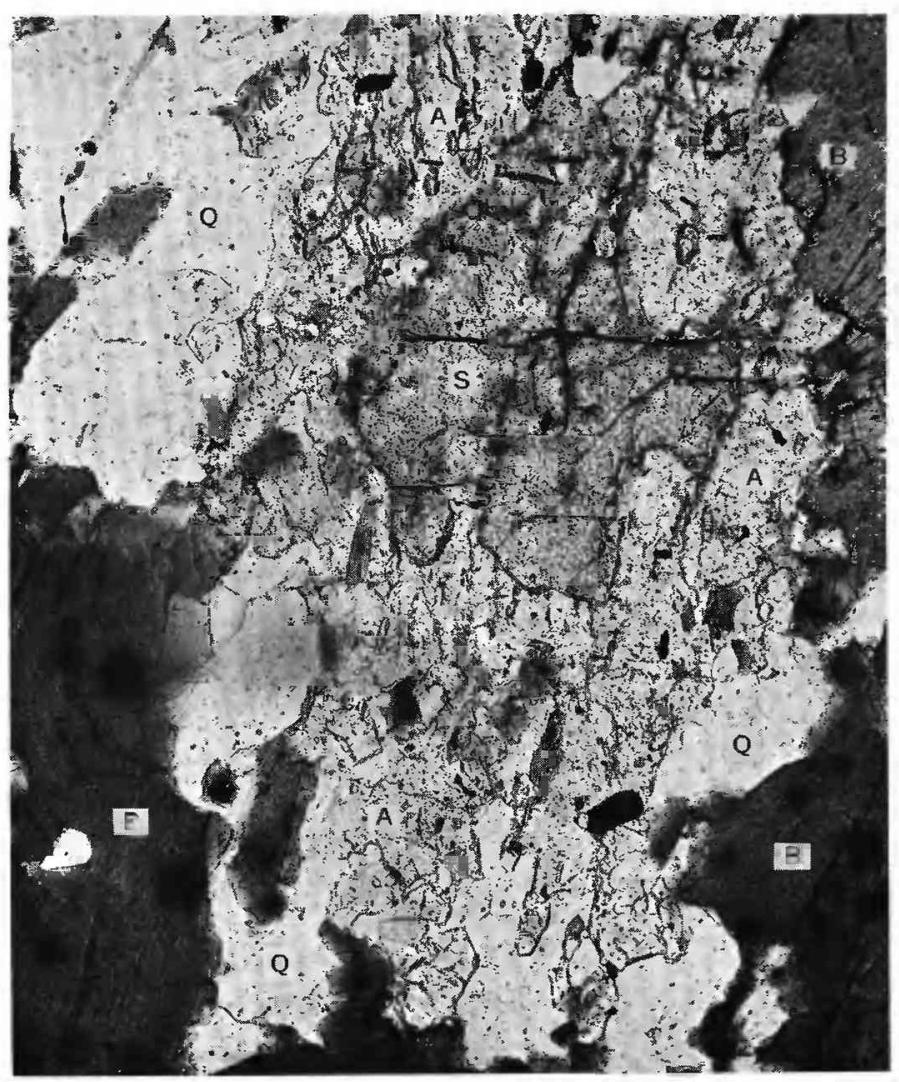

FIGURE 2.-Photomicrograph $(\times 75)$ showing staurolite $(5)$ surrounded by andalusite $(A)$, quartz $(Q)$, and biotite $(B)$.

1 This identification was made with the assistance of E. J. Young and confirmed with X-ray determinations by F. A. Hildebrand, U.S. Geological Survey, Denver, Colo. 
grains within an andalusite crystal generally have a uniform extinction position and are regarded as evidence that staurolite has been replaced by andalusite.

The relict microfolds are defined by folded trains of elongate opaque mineral particles in andalusite poikiloblasts and similar trains of quartz, opaque minerals, muscovite, biotite, and tourmaline in cordierite poikiloblasts. Figure $3 A$ shows a microfold outlined by trains of opaque minerals in a single crystal of andalusite. Figure $3 B$ shows microfolds similarly outlined by inclusions in cordierite. In both, the microfolds are restricted to the poikiloblasts, which themselves are undeformed, thus indicating that the microfolds were formed prior to the poikiloblasts.

Biotite and muscovite are intimately mixed in several different ways. About one-third of the specimens contain biotite in porphyroblastic subhedral to euhedral books as much as $3 \mathrm{~mm}$ across. The books are variously oriented at large angles to the compositional layering of the rock, but elongate quartz inclusions within them are parallel to the layering. Seams of muscovite that contain lines of minute opaque grains along cleavages

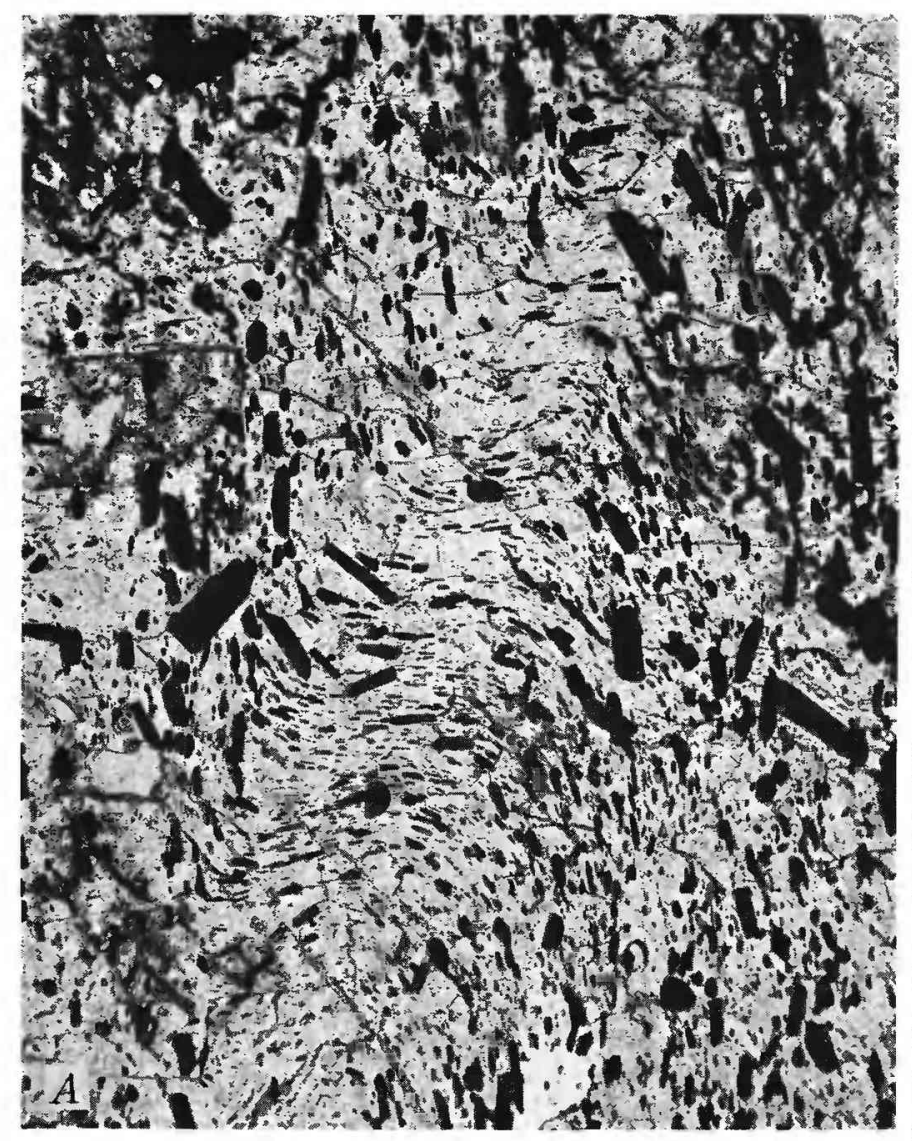

Figure 3.-A, Photomicrograph $(\times 77)$ showing folded alinements of opaque minerals poikilitically included in andalusite. $B$, Photomicrograph $(X 88)$ showing folded alinements of opaque minerals quart $(\mathrm{Q})$ and muscovite $(\mathrm{M})$ poikilitically included in cordierite (C).

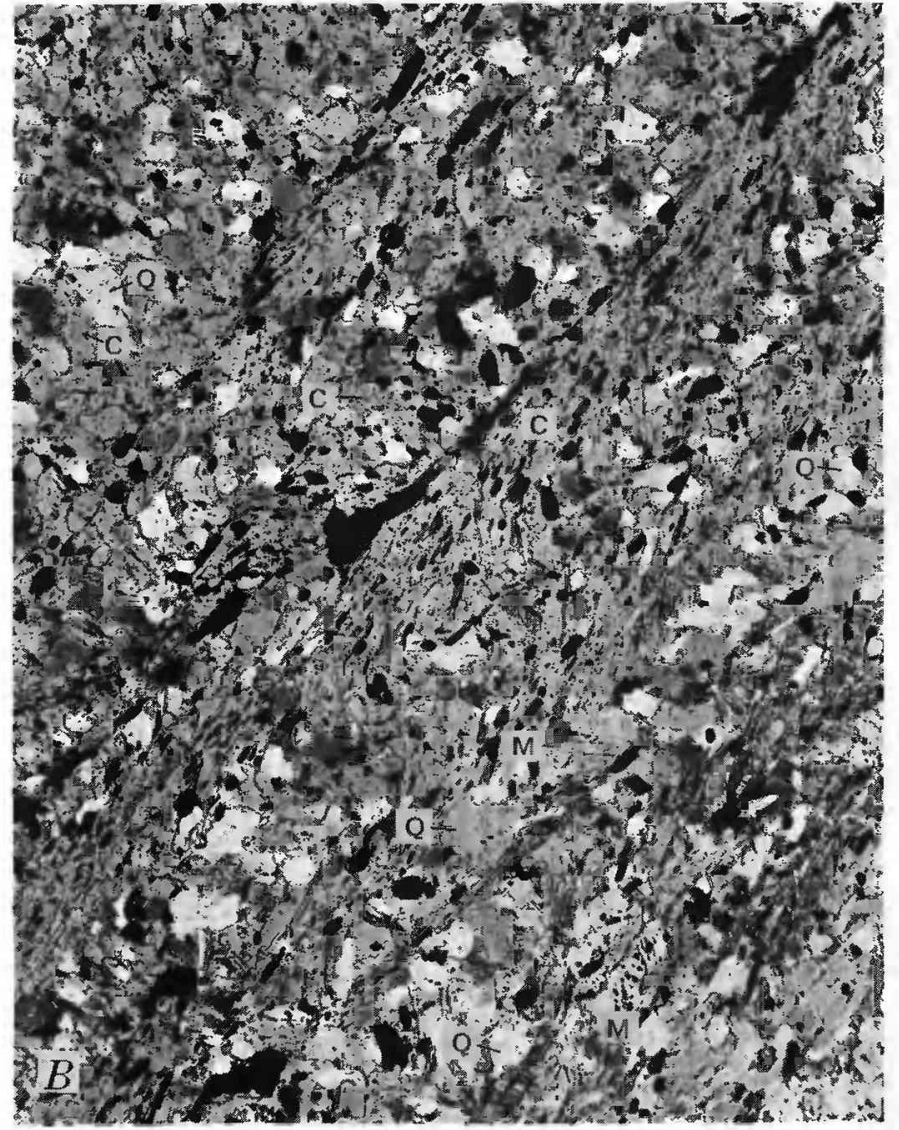

cut through some of the large biotite grains and are deflected around others. Both the muscovite and biotite are deformed by crinkling.

Other specimens show an intimate mixture of interlaminated muscovite and biotite in which some muscovite flakes cut biotite grains and others grade into the biotite along the length of the lamellae. Part of the muscovite contains minute opaque minerals along cleavage surfaces. All of the specimens show crinkling and some show cataclasis which has shredded the micas. The specimens in which deformation is slight show almost no muscovite.

Opaque minerals in the schist are magnetite-ilmenite, hematite, and leucoxene. Magnetite-ilmenite and hematite are ubiquitous and locally abundant. They occur as inclusions in andalusite, cordierite, and quartz, as lens-shaped grains between mica flakes, as diamondshaped crystals cutting through mica, and as irregular grains scattered through the rock. The dark color of the andalusite and of some outcrops of schist is due to the opaque minerals.

Chlorite is commonly present in the rock as an alteration product of biotite, garnet, and cordierite. Locally, chlorite flakes are oriented across the foliation of biotite flakes. 


\section{CALCIUM SILICATE ROCKS WITH SCHIST' IN} QUARTZITE

Quartz-rich calcium silicate rocks occur in pods or thin layers in the schist of the quartzite-schist sequence at two localities. One is on the south slope of Blue Mountain, near the center of the middle schist layer, and the other is on the south slope of Coal Creek Peak, near the upper contact of the upper schist layer. The rocks are layered and show a well-developed foliation that has been folded and cataclastically deformed to a moderate degree. They are fine grained and are green, gray, or white, depending on composition. The rocks consist of about 50 percent quartz, 30 percent epidote, and 20 percent of other minerals, including, in various places, biotite, plagioclase (oligoclase-andesine), potassic feldspar, garnet, tremolite, hornblende, and sphene. Opaque minerals, tourmaline, zircon, and apatite are present in traces (Sheridan and others, unpublished data). Some layers are rich in epidote, garnet, tremolite, and sphene and others are rich in quartz and microcline. Most of the grains are subhedral to anhedral. The garnet crystals are poikiloblastic and contain inclusions of plagioclase, quartz, epidote, and tremolite. Hornblende is skeletal and encloses quartz, epidote, and opaque minerals.

\section{IGNEOUS ROCKS}

The Precambrian igneous rocks in the area include Boulder Creek Granite (Lovering and Goddard, 1950), quartz monzonite, irregular bodies of hornblende diorite and associated hornblendite and irregular bodies and dikes of aplite, and dikes of pegmatite. All are younger than the metasedimentary rocks. The Boulder Creek Granite is older than the quartz monzonite, but both are closely associated in space, time, and geologic occurrence; they were intruded prior to the formation of the Idaho Springs-Ralston shear zone. The hornblende diorite and associated hornblendite are geographically separate from the other igneous rocks in small irregular bodies enclosed by metasedimentary gneisses. Even though these small bodies do not show conspicuous cataclastic effects, they probably were intruded prior to the formation of the Idaho SpringsRalston shear zone. The aplite and pegmatite are closely associated in small bodies intruded after most of the cataclasis in the Idaho Springs-Ralston shear zone had occurred.

The aplite and pegmatite are described under the general heading of igneous rocks even though a strict arrangement according to age would place the description after that of the cataclastic rocks.

\section{BOULDER CREFK GRANITE AND THE QUARTZ} MONZONITE

The Boulder Creek Granite in this area is gray, medium to fine grained, and locally porphyritic; it consists of quartz, plagioclase, potassic feldspar, and biotite aggregates. The quartz monzonite is fine grained and pinkish gray on fresh surfaces and light brown to grayish orange on weathered surfaces; it consists of quartz, feldspar, and fine scattered grains of muscovite and biotite. The two rocks are by far the most abundant igneous rocks in the area. They occupy most of the area northwest of the Coal Creek syncline and large sections south of the syncline (pl. 1). In addition, a phacolith of the Boulder Creek Granite lies in the keel of the syncline in the southwest part of the area, and small irregular bodies intrude the metasedimentary rocks south of the syncline.

Although the Boulder Creek Granite and the quartz monzonite are in bodies that follow the general outline of the Coal Creek syncline, they have discordant intrusive contacts with the metasedimentary rocks. This discordance is most obvious where quartzite bodies are surrounded by igneoulus rock, or where tongues of the igneous rocks extend into the metasedimentary rocks (pl. 1). Subtle discordance is shown where quartz monzonite cuts the lithologic layering of quartzite at a low angle on the south side of the Coal Creek syncline.

The Boulder Creek Granite and the quartz monzonite are probably nearly the same age because they have had similar geologic histories; but the granite is the older, as shown by exposures in South Boulder Creek, about 700 feet west of the map boundary. There, angular fragments of the Boulder Creek Granite are included in the quartz monzonite. In this same exposure, however, a foliation probably produced by minor cataclasis is continuous from one rock to the other. The discordance between foliation and contact shown here on a small scale is repeated on a larger scale in many places and is evident on the geologic map both north and south of the Coal Creek syncline.

The granite and quartz monzonite are believed to have been intruded late in the period of folding that produced the Coal Creek syncline. They cut through the folds of the syncline, but on the other hand, the granite intrudes the synclinal axis to form a phacolith, and both rocks contain lineations that were probably formed at the same time as the syncline. (See section on "structural geology".) Similar structural relations of intrusive bodies related to the Boulder Creek Granite have been recognized in the Ute Creek area southwest of Idaho Springs (Harrison and Wells, 1959). 
Foliation and lineation in the Boulder Creek Granite and the quartz monzonite appear to be largely of cataclastic origin. Both rocks show intense cataclasis in the Idaho Springs-Ralston shear zone and minor but pervasive cataclasis in most other places. In local areas northwest of the Coal Creek syncline, the rocks show no cataclasis, and the foliation and lineation may represent primary flow structure.

\section{BOULDER CREEK GRANITE}

The Boulder Creek Granite of the Coal Creek area is part of a batholith that is named for outcrops along Boulder Creek, several miles to the north. It is a gray medium- to fine-grained locally porphyritic rock that consists mainly of biotite, potassic feldspar, plagioclase, and quartz, and hornblende is present locally. The biotite characteristically occurs in aggregates. Phenocrysts of white or pink potassic feldspar as much as an inch long are locally common. Although referred to as granite, the Boulder Creek of this area ranges in composition from quartz monzonite to quartz diorite and has an average composition of plagioclase-rich quartz monzonite (fig. 4) (Sheridan and others, unpublished data). It contains $23-39$ percent quartz, $0-36$

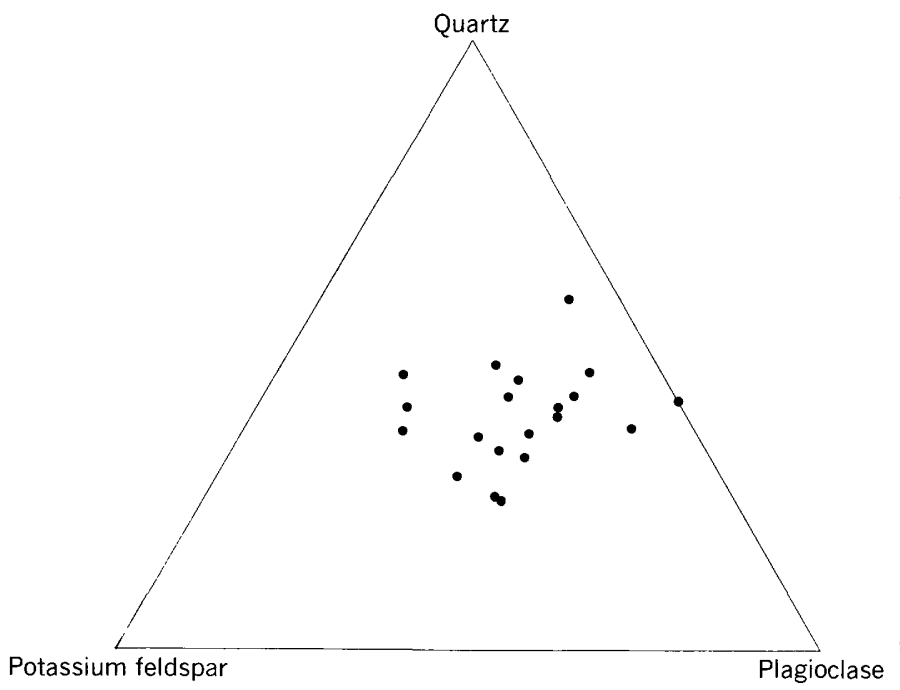

Frgure 4.-Triangular diagram showing variations in composition (volume percent) of part of the Boulder Creek Granite.

percent potassic feldspar, 14-49 percent oligoclaseandesine, trace to 33 percent biotite, $0-14$ percent muscovite, $0-2$ percent hornblende, trace to 2.4 opaque minerals, $0-3.3$ percent epidote, and 0 to trace of apatite, zircon, sphene, clorite, and allanite.

In the relatively undeformed rocks, the mica is predominantly biotite; but in the deformed rocks, late muscovite is abundant. In the Idaho Springs-Ralston shear zone, the micas have been shredded and recrystal- lized. Hornblende grains are subhedral and as much as $3 \mathrm{~mm}$ long in the undeformed rocks and are partly replaced by epidote and biotite in the intensely deformed rock. The opaque minerals, including magnetite-ilmenite and leucoxene, are mostly in minute irregular grains although some euhedral grains are present. Sphene forms rims around the irregular opaque mineral grains in some of the intensely deformed rocks and also occurs as individual crystals. Epidote replaces biotite and hornblende and forms layers in some of the cataclastic seams. Chlorite occurs mostly as an alteration product of biotite. Apatite, zircon, and allanite occur as scattered individual grains.

The textural results of the cataclasis are varied. The undeformed rocks contain large potassic feldspar and plagioclase phenocrysts. In the deformed rocks the phenocrysts are broken and poorly twinned, and some of them are reduced to residual augen in a granulated matrix. Fractures in some of the potassic feldspar are filled with biotite, quartz, and plagioclase. Vein and film perthite is common in the intensely deformed rocks but rare in the undeformed varieties.

An inconspicuous foliation results from parallel orientation of elongate aggregates of quartz and feldspar, of clusters of biotite, and locally, of phenocrysts. In areas of intense cataclasis, as in the Idaho SpringsRalston shear zone, the quartz-feldspar aggregates and biotite clusters are smeared out and the rock appears gneissic. This conspicuous secondary foliation locally cuts across the earlier and weaker foliation. Lineations are inconspiuous in the relatively undeformed rocks but conspicuous in the intensely deformed rocks of the Idaho Springs-Ralston shear zone. They are defined by rod-shaped quartz-feldspar aggregates and by elongate biotite clusters.

\section{QUARTZ MONZONITE}

The quartz monzonite differs from the Boulder Creek Granite in that it generally contains muscovite as well as biotite, and the biotite is in flakes rather than in clusters. It is a gray rock that weathers pinkish gray and is locally porphyritic. Two varieties, one fine grained and the other medium grained, have been recognized. On South Boulder Creek, angular fragments of the medium-grained rock are included in the finegrained variety, showing that the fine-grained rock there is the younger, but in many places the two varieties intergrade.

The composition of the quartz monzonite as determined from 19 modes is indicated in figure 5. The rock contains 29-45 percent quartz, $19-36$ percent potassic feldspar, 15-35 percent oligoclase, trace to 10 percent biotite, trace to 16 percent muscovite, trace to 2.7 per- 


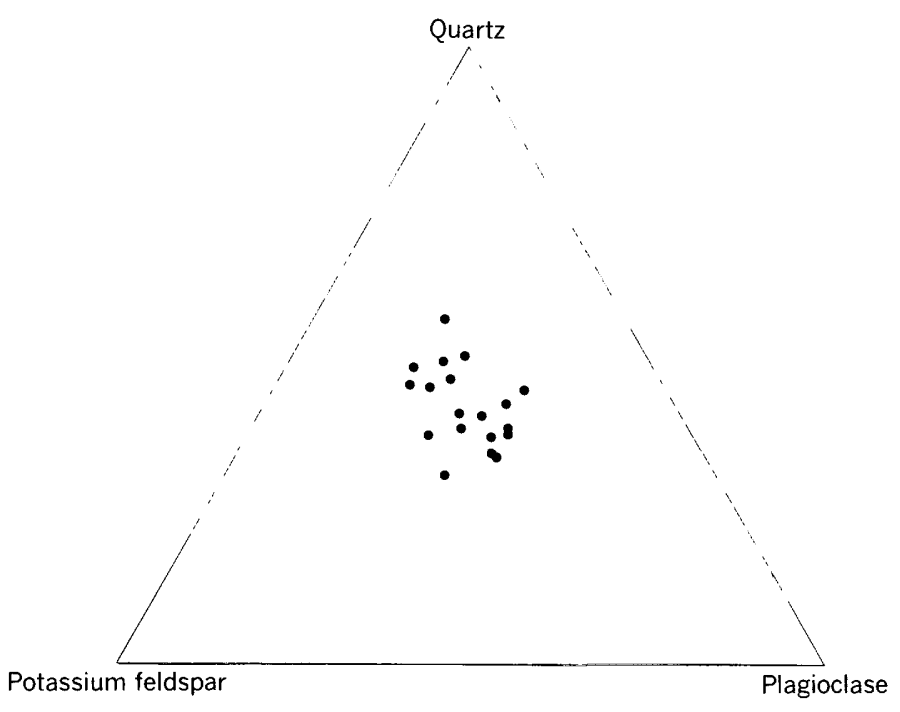

Fradre 5.-Triangular diagram showing variations in composition (volume percent) of the quartz monzonite.

cent opaque minerals, and 0 to trace amounts of apatite, epidote, zircon, sphene, chlorite, and garnet. (Sheridan and other, unpublished data.)

Most of the quartz monzonite north of the Coal Creek syncline shows moderate to slight cataclasis that resulted in a weak foliation and lineation formed by the alinement and streaking of biotite flakes. In the Idaho Springs-Ralston shear zone south of the syncline, foliation formed by intense cataclasis cuts the early weak foliation. In the rocks affected by cataclasis, the large grains of potassic feldspar are broken, and the fractures are filled with biotite, quartz, and plagioclase. The potassic feldspar displays an increasing amount of perthite with increasing cataclasis, and both the plagioclase and potassic feldspars show less twinning. Muscovite has replaced biotite and is more abundant than biotite in the most deformed rocks. In some of the most deformed specimens, sphene forms rims around irregular opaque mineral grains, and epidote forms aggregates in layers parallel to the shear surfaces.

HORNBLENDE DIORITE AND HORNBLENDITE

Hornblende diorite and hornblendite occur together and are believed to be closely related in origin. They crop out in the southeastern part of the area, where the northern end of a large body of hornblende diorite and smaller bodies of diorite and hornblendite are exposed (pl. 1). All the bodies of hornblende diorite and hornblendite occur within the microcline gneiss and hornblende gneiss unit.

The hornblende diorite is a mottled black and palegray rock. Large black grains of hornblende, commonly 5-20 $\mathrm{mm}$ in length are set in a fine- to medium- grained matrix of plagioclase and hornblende. The large grains give the rock a spotted appearance that is especially conspicuous on weathered surfaces. The diorite contains about 35 percent hornblende, 60 percent plagioclase (labradorite), and trace amounts of biotite, apatite, opaque minerals, rutile, and sphene (Sheridan and others, unpublished data). Although some of the hornblende diorite is poorly foliated, most of it is moderately to well foliated, and hornblende grains are alined in the foliation planes. The foliation and lineation in the hornblende diorite appear to be parallel to the structures in the adjacent metasedimentary rocks.

The hornblendite is a poorly to moderately well foliated black to greenish black medium- to coarse-grained rock that consists predominantly of hornblende. It contains about 95 percent hornblende in grains $0.1-3$ $\mathrm{mm}$ long and trace amounts of plagioclase, biotite, apatite, and opaque minerals. Alternation products, including chlorite, epidote, and sericite, are abundant locally.

\section{PEGMATITE AND APLITE}

Pegmatite occurs in dikes a few tens of feet wide and a few thousand feet long, and in rounded to irregular bodies less than 500 feet across, in the metamorphic and igneous rocks south of the Coal Creek syncline (pl. 1). North of the syncline, a few pegmatite dikes and a larger body of mixed pegmatite and aplite intrude the Boulder Creek Granite and the quartz monzonite. Both areas contain many small bodies of pegmatite not shown on the map. Only one pegmatite is known to cut quartzite. Most of the pegmatite bodies are crosscutting and clearly younger than any of the other rocks.

The pegmatite bodies lie in the cataclastic belt but are undeformed. This suggests that they belong to the youngest period of Precambrian igneous activity in the region, probably the episode during which the Silver Plume Granite was emplaced (Lovering and Goddord, 1950, p. 28; Harrison and Wells, 1956, p. 54-56). Pegmatite similar to that of Coal Creek, together with aplite, is traceable into bodies of Silver Plume Granite 3 miles north of the mapped area.

The pegmatite bodies consist mainly of quartz and perthitic microcline and lesser amounts of muscovite, biotite, plagioclase, and tourmaline. Locally the pegmatite bodies in the Ralston Buttes quadrangle contain beryl, chrysoberyl, apatite, magnetite-ilmenite, garnet, allanite, monazite, triplite, sillimanite, and an unidentified violet-blue mineral containing iron and phosphate (Sheridan and others, unpublished data).

The aplite in the northern part of the area consists principally of microcline, plagioclase, quartz, and minor quantities of mica. 


\section{CATACLASTIC ROCKS}

The Idaho Springs-Ralston shear zone in the southern part of the map area (pl. 1) contains many varieties of intensely deformed rock. Some of these grade into lessdeformed rocks, or can be identified as to parent material because of distinctive composition. Others, however, cannot be correlated with parent rocks and hence have been mapped separately. Two varieties, augen gneiss and cataclastic gneiss are recognized. The augen gneiss characteristically contains conspicuous small pink feldspar augen in a well-foliated biotitic matrix; the cataclastic gneiss is mostly a granular poorly foliated quartz-feldspar rock accompanied by a minor amount of well-foliated biotitic rock. As map units, each contains small bodies of the other, and contacts between the two units are generally gradational.

\section{AUGEN GNEISS}

The augen gneiss unit lies along the southern boundary of the Idaho Springs-Ralston shear zone (pl. 1). The unit is about 2,000 feet thick in the northeastern part and thins to less than 100 feet to the southwest. It encloses layers or lenses of the hornblende gneiss unit in many places. Near Coal Creek, these are large enough to show on the map; but to the southwest, they are too small and are included with the augen gneiss unit.

The augen gneiss is a fine-grained well-foliated rock ranging from pinkish gray to pink. It is characterized by white to pink porphyroclasts of feldspars $0.2-2.5 \mathrm{~mm}$ in diameter in a fine-grained matrix. The rock is composed mostly of quartz, plagioclase, and potassic feldspar, and lesser amounts of biotite, muscovite, and, locally, microantiperthite. Modes of the gneiss (Sheridan and others, unpublished data) show 40-48 percent quartz, 5-30 percent potassic feldspar, 17-33 percent plagioclase (sodic oligoclase), 0-12 percent microantiperthite, $3-10$ percent biotite, and a trace to 6 percent muscovite, trace to 2 percent clinozoisite-epidote, trace to 3 percent opaque minerals, and 0 to trace amounts of apatite, garnet, zircon, sphene, sericite, and chlorite. Most thin sections of augen gneiss show conspicuous mortar structure and a succession of parallel granulated zones. In some of the granulated areas, some of the quartz and mica are ungranulated and may have recrystallized.

\section{CATACLASTIC GNEISS}

The cataclastic gneiss unit forms a belt within the biotite gneiss and mica schist unit between Coal and Ralston Creeks (pl. 1). The belt is 400-900 feet wide except at its southwest end, where it pinches out just short of a junction with the augen gneiss.
The cataclastic gneiss consists principally of layers or zones of poorly foliated fine-grained light-colored quartz-feldspar rock alternating with thinner layers of slightly coarser dark biotitic gneiss that contains feldspar augen. Toward the northeast the light-colored quartz-feldspar fraction grades into a mottled green and pink poorly foliated epidote-quartz rock. A specimen of the dark gneiss contains 34 percent quartz, 2 percent potassic feldspar, 37 percent plagioclase (andesine), 22 percent biotite, 2 percent epidote-clinozoisite, 2 percent opaque minerals, and a trace of sphene, zircon, apatite, allanite, and sericite (Sheridan and others, unpublished data). A specimen of the light-colored gneiss contains 48 percent quartz, 27 percent potassic feldspar, 12 percent plagioclase (oligoclase), 2 percent biotite, 8 percent muscovite, 2 percent epidote-clinzoisite, and a trace of opaque minerals, apatite, allanite, and sericite. A specimen of the quartz-epidote rock contains 25 percent quartz, 74 percent epidote, and a trace of opaque minerals, sphene and sericite. Thin sections of these rocks show pervasive crushing and many parallel or anastomosing granulated zones. These zones may contain younger and undeformed epidote or muscovite.

\section{STRUCTURAL GEOLOGY}

Three periods of Precambrian deformation are recognized in the quartzite-schist sequence of the Coal Creek syncline: two early periods of plastic folding and a late period of cataclasis. The last two periods are believed equivalent to the two periods that have been described in the Central City-Idaho Springs area (Harrison and Wells, 1956 and 1959; Moench and others, 1962).

The similarities between the structural history of the quartizite-schist sequence and that of the gneisses typical of the Idaho Springs Formation throughout the central Front Range indicate that the quartzite-schist sequence is not young and relatively undeformed but rather is as old as the typical Idaho Springs and has experienced the same deformation events.

\section{STRUCTURAL FEATURES}

Practically every outcrop in the area is foliated, and most also show one or more lineations. In the metasedimentary rocks that have not been affected by cataclasis, foliation is shown by the parallel arrangement of platy minerals, mostly muscovite and biotite, and by layering defined by color, textural variations, or composition. The foliation surfaces are parallel to the layering except locally where crosscutting foliation has been formed by shearing in drag folds, slip cleavage, or axial plane shear. Lineations are represented in these rocks by fold axes and by mineral alinements on the foliation surfaces. The mineral lineations are 
expressed by alinements of three general types: (1) elongate minerals such as sillimanite and hornblende, (2) elongate aggregates of platy or equidimensional minerals such as biotite, muscovite, or quartz, and (3) boudinage.

In the igneous rocks the foliation is generally inconspicuous and is caused by the planar arrangement of aggregates of biotite and of quartz and feldspar. The lineations result from linear arrangement of these aggregates. Most of these structures result from minor cataclasis, although some are flow structures.

In the Idaho Springs-Ralston shear zone and in small local areas outside the zone, through-going shear surfaces have modified or obliterated preexisting planar and linear structures. In such places, the minerals have been reoriented mechanically or by recrystallization to define new foliation and lineation.

\section{THREE PERIODS OF DEFORMATION}

The relations among the structural elements in the area establish three periods of Precambrian deformation: (1) an early period of plastic folding that predates the Coal Creek syncline, (2) the plastic deformation that formed the Coal Creek sycline and small parallel folds, and (3) the late cataclastic deformation.

The Coal Creek syncline is the principal structural feature in the Precambrian rocks of the area (pl. 1). The syncline has a plunge and bearing ranging from about $10^{\circ} \mathrm{N} .60^{\circ} \mathrm{E}$. in its western part to about $30^{\circ} \mathrm{N}$. $65^{\circ} \mathrm{E}$. in its eastern part. In the southeastern part of the area, a small anticline and syncline, whose axes are nearly parallel to the Coal Creek syncline, plunge steeply southwestward (pl. 1). Within the Coal Creek syncline are minor folds with amplitudes and wavelengths of a few tens of feet and a N. $80^{\circ} \mathrm{E}$. trend. These folds have been mapped in the Coal Creek Peak area and have been observed, although not mapped elsewhere.

The Coal Creek syncline ranges from open to nearly isoclinal, is overturned, and has a moderately steep north limb and a nearly vertical south limb. The small parallel folds to the south are open as shown in the cross sections (pl. 1). The N. $80^{\circ}$ E. folds are open to isoclinal, and its axial planes are nearly vertical. Drag folds and minor warps and crinkles are of various trends. The folding is disharmonic owing to the flowage of the less competent beds. As a result, the schistose units are thickened in the crests of folds and are more intensely folded than the quartzite and feldspathic units. This is shown on Coal Creek west of Coal Creek Peak and near Nott Creek (pl. 1).

Mineral lineations have been warped by drag folds in many places in the Coal Creek syncline. A typical example is shown in figure 6. The fold is one of the minor folds whose axis is parallel to the Coal Creek syncline, and the mineral lineation is typical of those that most commonly plunge to the southwest. On both limbs, the lineation forms an angle of about $65^{\circ}$ with the axis of the fold and thus defines an originally straight line that lies at an angle of about $25^{\circ}$ to the $a$ lineation formed by the folding (following the usage of Cloos, 1946, p. 5). This relation strongly indicates that the diagonal lineation is a product of a period of deformation that predated the folding of the Coal Creek syncline.

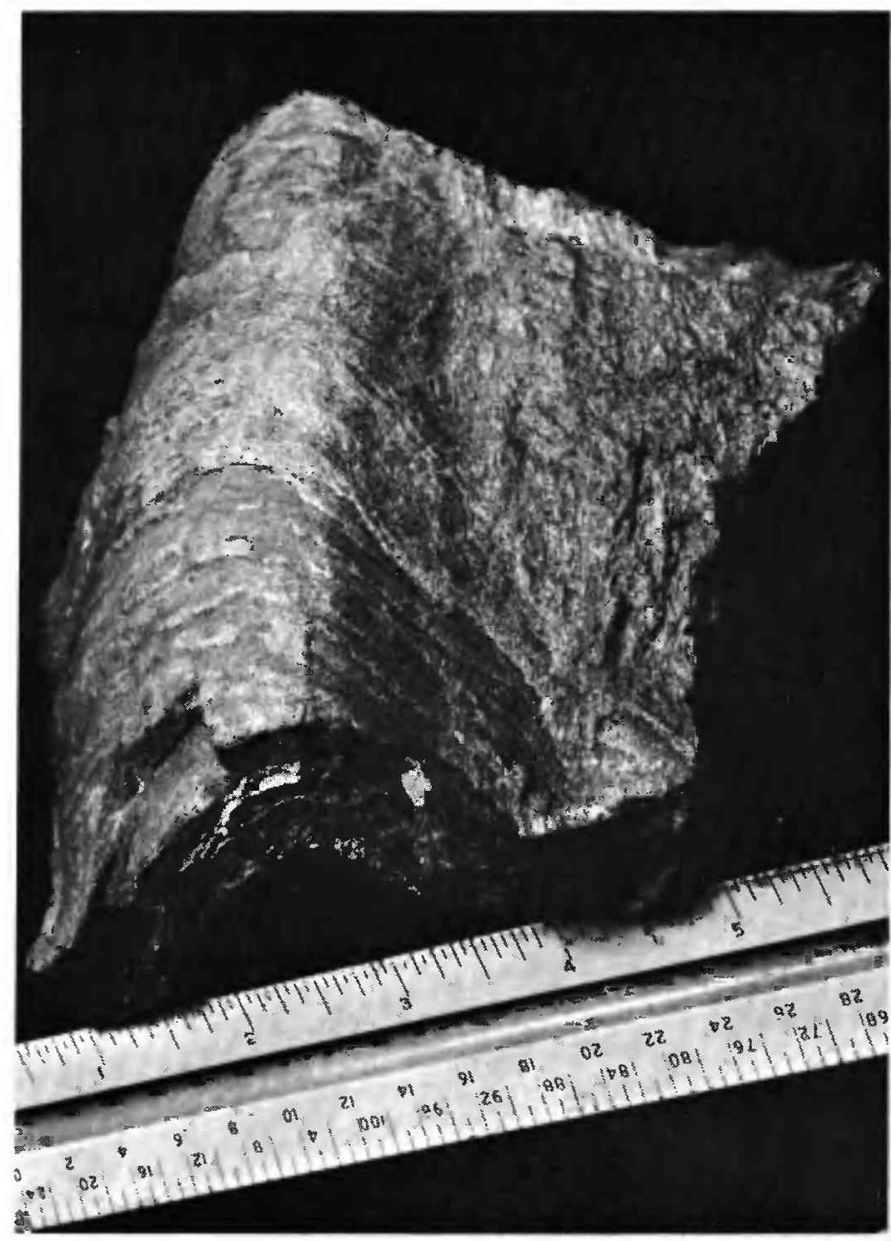

Figure 6.-Hand specimen of quartzite showing early-formed lineation warped by a drag fold representative of the Coal Creek syncline.

The structural characteristics of the deformation that preceded the folding of the Coal Creek syncline are not known because all the preexisting lineations have been subject to rotation, and no fold that predates the Coal Creek syncline has been found in the area.

Rocks with intense cataclastic deformation characterize the Idaho Springs-Ralston shear zone (Tweto and Sims, 1963), south of the Coal Creek syncline. The shear zone is about 0.5 of a mile wide in the northeastern 
and southwestern parts of the map area and 1.5 miles wide in the central part (shaded area, pl. 1). The southern boundary of the shear zone is sharply defined by the cataclastic gneisses, but the northern boundary is gradational. Bodies of cataclastically deformed quartzite and schist are widely scattered north and south of the shear zone as mapped. The shear zone trends about $\mathrm{N}$. $50^{\circ} \mathrm{E}$. and dips steeply. Within it, the intensity of cataclasis varies widely, and bodies of intensely deformed rock enclose and grade into bodies of almost undeformed rock. Where cataclasis was intense, a new foliation parallel to shear planes cuts and commonly destroys earlier structures, and mineral streaking and slickensides on the new foliation surfaces form a conspicuous lineation. In such places, the rocks have been finely ground, but not to a paste as they contain remnants of the original rock in augen and pods and lenses of virtually undisturbed rock. Schistose rocks do not show shear zones so readily as feldspathic rocks but generally appear as highly contorted or crinkled rocks.

The cataclastic foliation in the southwestern part of the area has been cast into drag folds with either northeast or southwest plunges and relative movements of south side up on some and north side up on others. Along Coal Creek in the northeastern part of the cataclastic belt, the cataclastic foliation is broadly warped. Because these features are rather limited in extent and magnitude, they probably represent minor adjustments within the shear zone itself during the last phases of cataclastic deformation.

The cataclastic foliation of the shear zone cuts and obliterates the widespread earlier foliation and lineation in the metasedimentary rocks, the Boulder Creek Granite, and the quartz monzonite but does not affect the pegmatite. Thus, the cataclasis in the Idaho Springs-Ralston shear zone occurred after folding of the Coal Creek syncline and instrusion of the granitic rocks, but before pegmatite dikes related to Silver Plume Granite were emplaced.

Tentative correlations of the last two periods of deformation with the structures described in the Idaho Springs-Central City area (Moench and others, 1962) may be made. The early period of deformation in the Coal Creek area is not recognized with certainty at Central City and Idaho Springs, although there could have been an early period of folding. The second period of deformation in the Coal Creek area is probably equivalent to the oldest recognized folding in the Idaho Springs-Central City area because the Boulder Creek Granite was intruded and the major folds were formed at this time in both places.
The cataclastic deformation is a feature of the Idaho Springs-Ralston shear zone, which extends to the Idaho Springs-Central City area (Lovering and Goddard, 1950; Tweto and Sims, 1963), and is there both cataclastic and plastic in nature. It is thus equivalent to the second period of deformation recognized in the Idaho Springs-Central City area (Moench and others, 1962). In the Idaho Springs area the shear zone is considered to have been formed in a deep environment because of the plastic deformation associated with it (Harrison and Wells, 1959, p. 32). As seen in the Coal Creek area, it is probably a product of shallower depth, but deep enough that high-grade minerals were not destroyed.

\section{ORIENTATION OF LINEATIONS}

The linear elements in the rocks of the Coal Creek area have a wide range in attitude but statistically show several preferred orientations. Some of these preferred orientations are known from field observations to be products of one of the three periods of Precambrian deformation, and the others may be interpreted or inferred to be related to these also.

Several geographic areas or sectors enclosing structural and (or) lithologic units have been outlined (fig. 7) and satistical plots of the lineations made on an equal area net. This enables one to evaluate differences in magnitude and orientation of the statistical highs in the different sectors.

It has already been noted that the bearing and plunge of the axis varies along the Coal Creek syncline. Contour diagrams of statistical plots of the axes of minor folds in the Crescent Mountain, Blue Mountain, and Nott Creek sectors (figs. 7, 8) show both the major and the minor northeastward-plunging axes and their variations in orientation. These are designated $T$ and $U$ respectively. From the western to the eastern sectors the average attitude of $T$ ranges from $20^{\circ} \mathrm{N} .60^{\circ} \mathrm{E}$. to $18^{\circ} \mathrm{N}$. $58^{\circ} \mathrm{E}$. to $34^{\circ} \mathrm{N}$. $62^{\circ} \mathrm{E}$. and $U$ ranges from $20^{\circ}$ N. $80^{\circ}$ E. to $45^{\circ}$ N. $85^{\circ}$ E. to $40^{\circ}$ N. $79^{\circ}$ E. In general, the bearing has less variation than the plunge.

The southeast metasedimentary sector (fig. 8) includes the small folds that are parallel to the Coal Creek syncline, but the folds plunge southwest. Component $W$ shows the average bearing and plunge to be $52^{\circ} \mathrm{S} .65^{\circ}$ W. The maximum includes lineations formed by fold and crinkle axes and by mineral alinements. Some of the mineral alinements included in this maximum may be of cataclastic origin as will be shown later. Component $W$ is weakly formed in the Blue Mountain and Nott Creek sectors (fig. 8) but component $U$ especially is well represented in the southeast metasedimentary 
PRECAMBRIAN QUARTZITE SCHIST, FRONT RANGE, COLO.

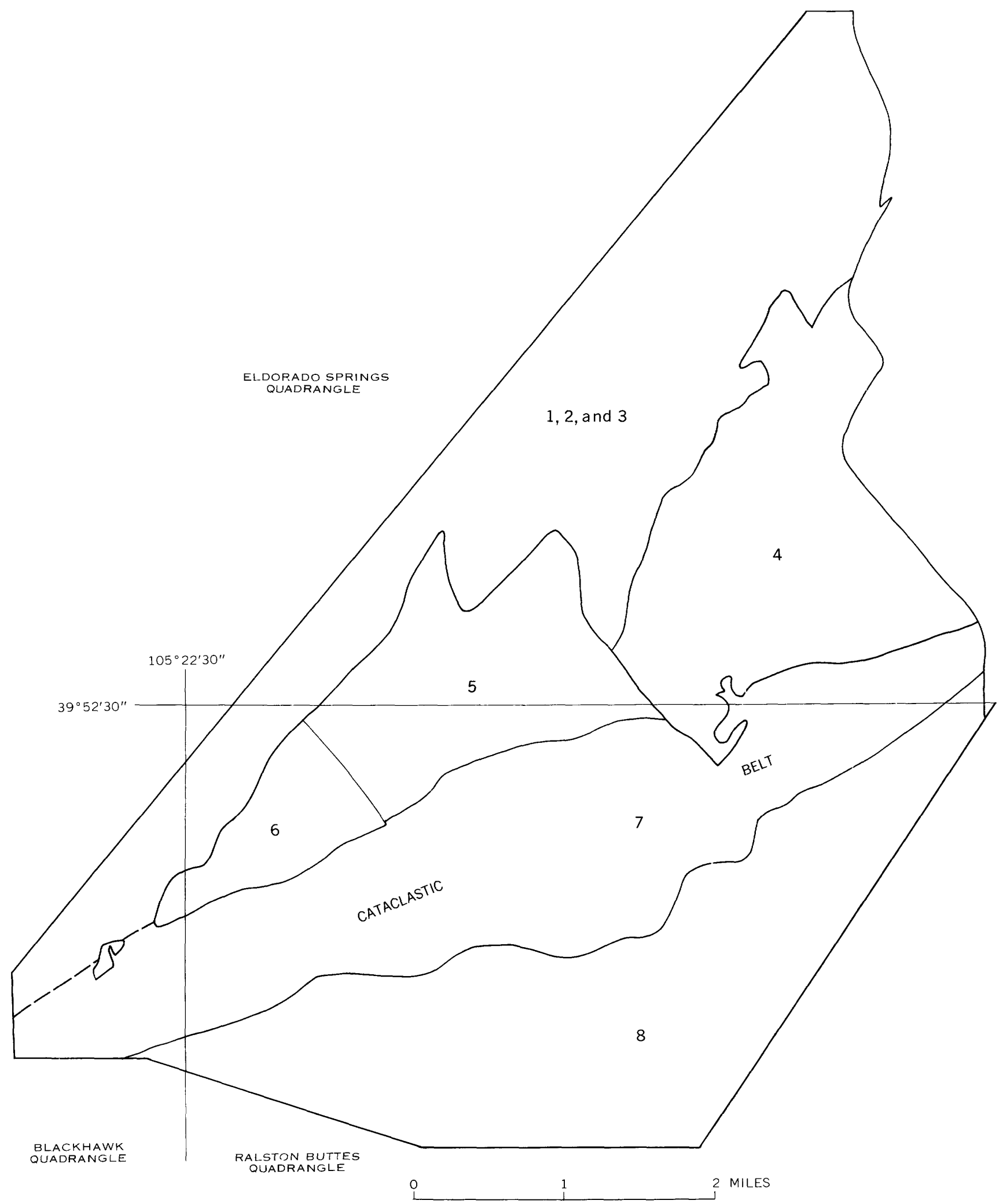

Figure 7.-Index map showing generalized boundaries of following sectors represented by contour diagrams (pl. 1). 1. Northwest quartzite-all bodies surrounded by igneous rocks. 2. Northwest Boulder Creek-Boulder Creek Granite in Eldorado Springs quadrangle. 3. Northwest quartz monzonite-quartz monzonite in Eldorado Springs quadrangle. 4. Crescent Mountain-quartzite and schist along Coal Creek syncline east of Rogers fault. 5. Blue Mountain sector-quartzite and schist along Coal Creek syneline between Rogers and Hurricane Hill faults. 6. Nott Creek-quartzite and schist along Coal Creek syncline west of Hurricane Hill fault. 7. Cataclastic belt-all rocks that show conspicuous cataclasis. 8. Southeast metasedimentary-metasedimentary rocks without conspicuous cataclasis in the southeast part of the area. 


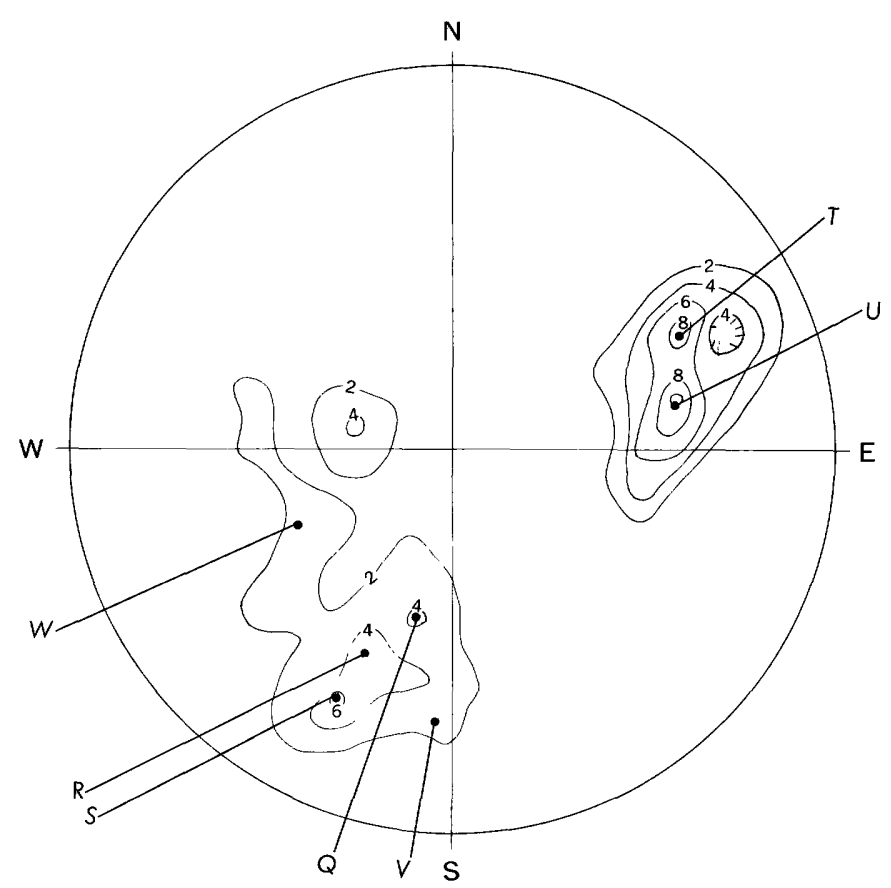

CRESCENT MOUNTAIN SECTOR 109 lineations

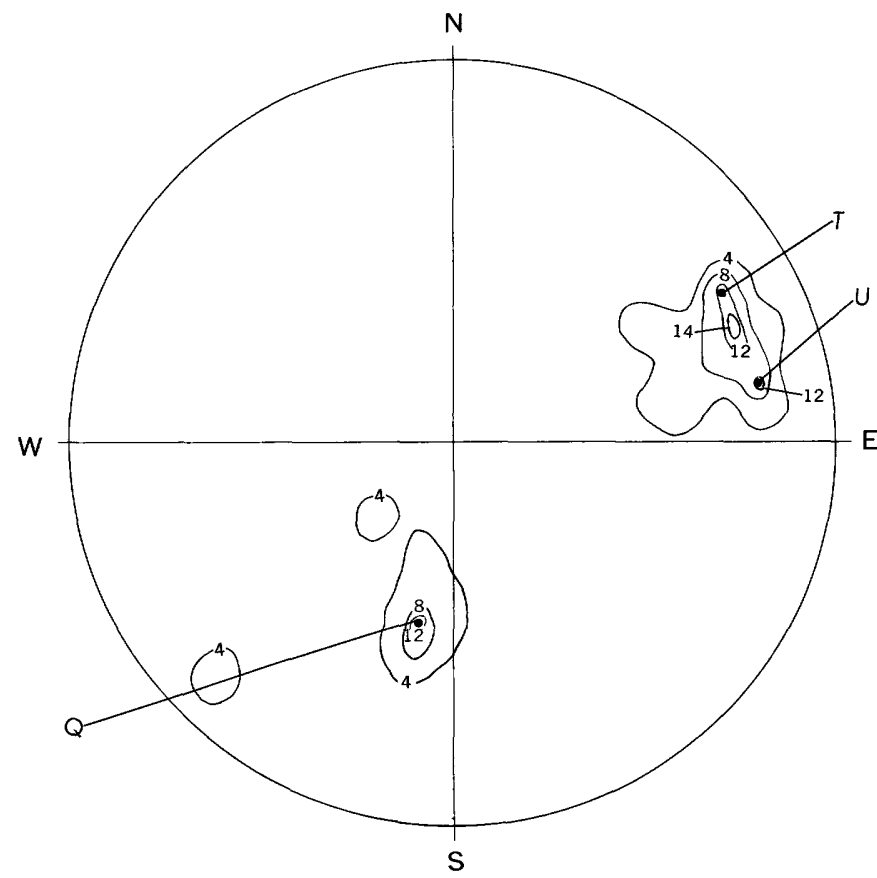

NOTT CREEK SECTOR 32 lineations

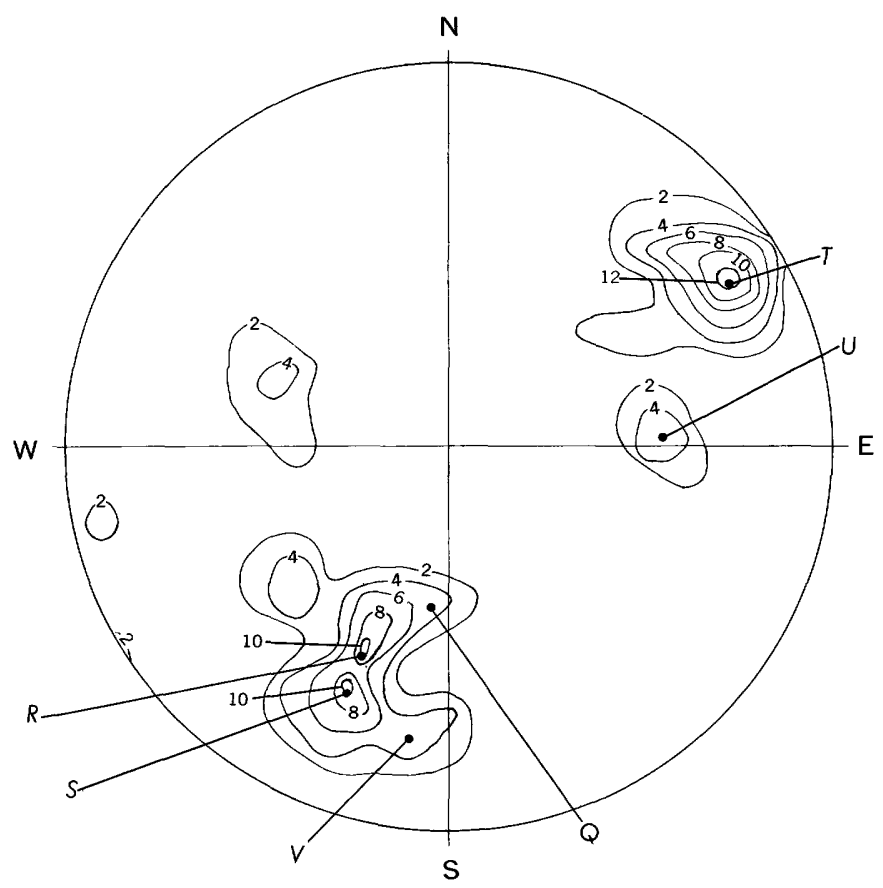

BLUE MOUNTAIN SECTOR 67 lineations

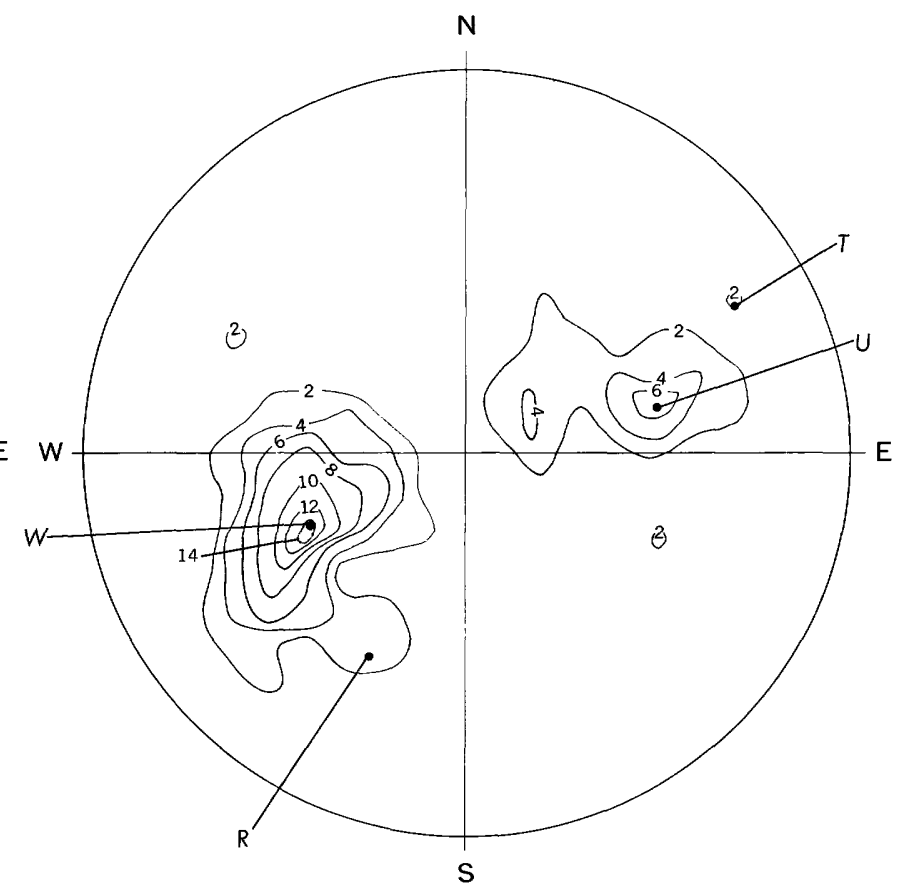

SOUTHEAST METASEDIMENTARY SECTOR 92 lineations

FIGURE 8.-Contour diagrams of lineations (lower hemisphere plot). Contoured in percent. Letters Indicate concentrations of lineations referred to in the text. 
sector (fig. 8). Possibly the steep northeastwardplunging maximum in the southeast-metasedimentary sector represents a local area of steepening along axes parallel to the Coal Creek syncline.

The cataclastic belt (fig. 7) encloses the intensely sheared rocks of the Idaho Springs-Ralston shear zone, which trends $\mathrm{N} .50^{\circ}-55^{\circ} \mathrm{E}$. Steep lineations are formed on the shear surfaces. The contour diagram of this sector (fig. 9) shows a maximum with a bearing and plunge of $56^{\circ} \mathrm{S} .15^{\circ} \mathrm{W}$., designated $Q$ that represents the average orientation of these lineations. Component $Q$ is representative of only the southwestern end of the cataclastic belt. The broad concentration about center $W$ contains lineations from both the northeastern and southwestern parts; those of flatter plunge are mostly from the northeastern part. Component $Q$ is present in the Crescent Mountain, Blue Mountain, and Nott Creek sectors (fig. 8), and a concentration around component $W$ is shown only to a minor extent. The Mineral alinement included with component $W$ in the southeast metasedimentary sector (fig. 8) are partly cataclastic in origin.

The igneous rocks northwest of the Coal Creek syncline contain mineral alinements represented by two maxima designated $S$ and $V$. These appear on the diagrams for both the northwest Boulder Creek and northwest quartz monzonite sectors (figs. 7, 9). These are present not only in the igneous rocks but also in the metasedimentary rocks of the Crescent Mountain and Blue Mountain sectors (fig. 8) although component $V$ is not conspicuous in the Crescent Mountain sector. Considering that both kinds of igneous rocks border the Coal Creek syncline and the Boulder Creek intrudes the syncline phacolithically, the occurrence of $S$ and $V$ in the metasedimentary sectors suggests that these components originated with the Coal Creek syncline and are related to components $T$ and $U$. Considering the Coal Creek syncline in its more general aspect, components $T$ and $U$ combined represent the axis of the syncline, and following the common usage of Cloos $(1946$, p. 5) can be designated as the $b$ axis of the fold. The direction of $S$ and $V$ combined is about $90^{\circ}$ from the $b$ axis and can be considered the $a$ axis of the fold.

The lineations that form the $a$ axis in the igneous rocks appear on foliation surfaces formed by the minor pervasive cataclasis. They therefore, had to have formed after the igneous rocks solidified, but not necessarily long after. Their geometric relation to the syncline suggests that they formed while the forces that created the syncline were still in some part existent. On the other hand, as the massive rock of the Boulder Creek Granite and the quartz monzonite are not likely to have folded along with the bedded quartzite and schist of the syncline after it was completely consolidated, it is concluded that these rocks were intruded during the waning stages of folding (after the syncline had attained almost its present form, but before the stresses that created it had relaxed completed. In response to the differential movement of the igneous rocks as a mass with respect to the syncline as another mass, cataclasis and the formation of lineation probably occurred as soon as any part of the igneous body became solid, and while its main bulk was still liquid at depth.

Both contour diagrams of the igneous rocks show maxima that are not coincident with any maximum in the other diagrams. Interpretation of these cannot be made because structural data on the igneous rocks outside the Coal Creek area have not been collected.

Lineations in the outliers of quartzite surrounded by igneous rocks northwest of the Coal Creek syncline, northwest quartzite sector (fig. 9), contain some of the same lineation attitudes as the nearby Crescent Mountain sector. Component $R$ is the same as in the Crescent Mountain sector (fig. 8); the $S$ component is somewhat flatter than typically represented along the Coal Creek syncline; and $T$ is less well defined.

It has been pointed out that very little can be determined about the structural deformation that occurred before the Coal Creek syncline was folded, but the probability exists that the lineation maximum which plunges southwest and is designated $R$, on the diagrams represents the most common orientation of the early mineral alinement. This component is present in the Crescent Mountain, Blue Mountain, southeast metasedimentary and the northwest quartzite sectors and is absent from the Nott Creek sector, the igneous rocks, and cataclastic rocks. The strong cataclasis apparently obliterated the $R$ component in the cataclastic sector and possibly in the Nott Creek sector. Probably the $R$ component is absent from the igneous rocks because they were intruded after its formation. All other maximums that recur in several diagrams have been accounted for, and it may be inferred that $R$ represents the lineation formed before the folding of the Coal Creek syncline and the intrusion of the igneous rocks.

In summary, the earliest recognized period of Precambrian folding formed mineral lineations which have a south-southwestward plunge in this area. This component, represented by $R$ on the contour diagrams, is found only in the metasedimentary rock units. The second recognized period of folding warped the $R$ component mineral alinements and formed the Coal Creek syncline, which consists of two northeastward-plunging components $-T$ and $U$ at N. $60^{\circ}$ E. and N. $80^{\circ}$ E., 

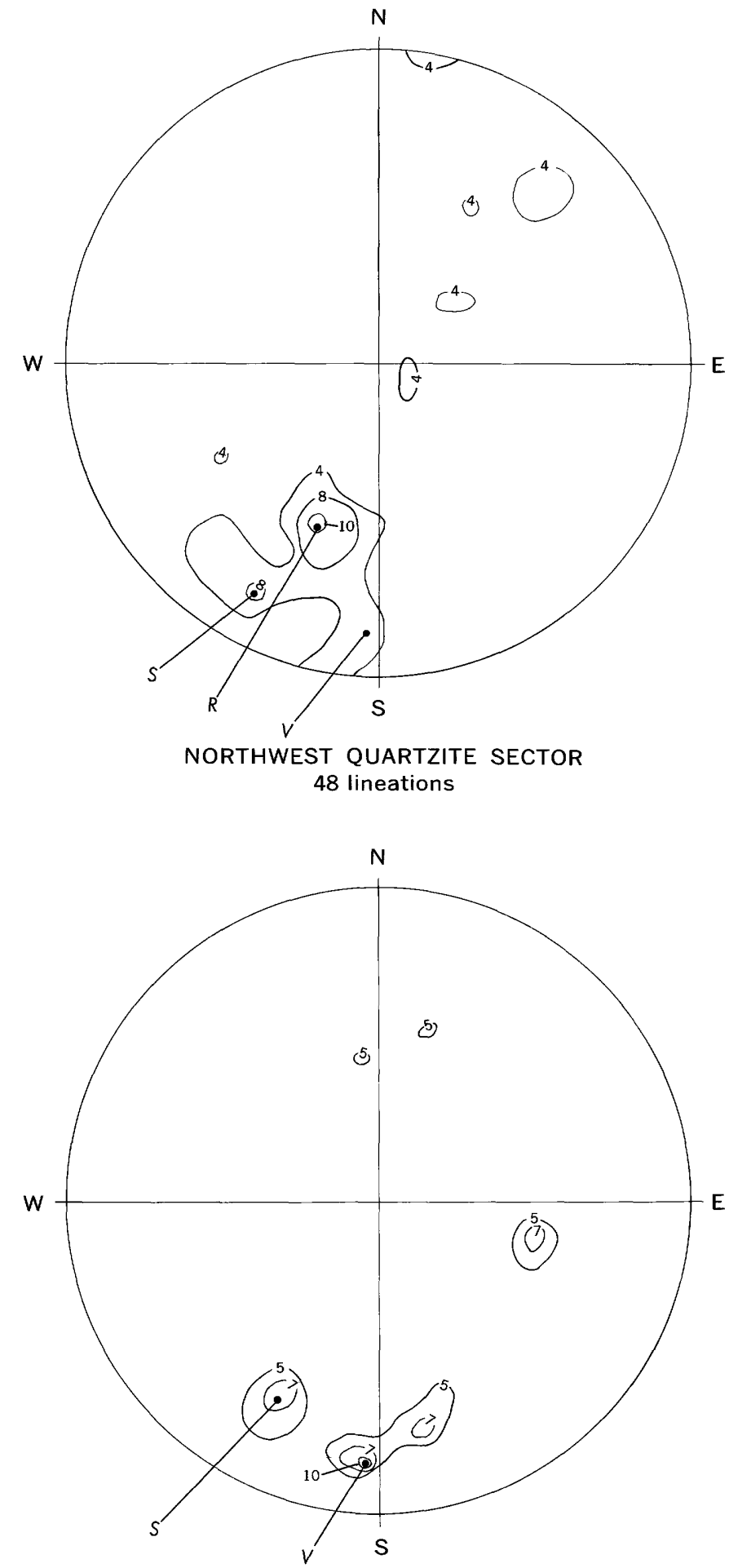

NORTHWEST BOULDER CREEK SECTOR 53 lineations

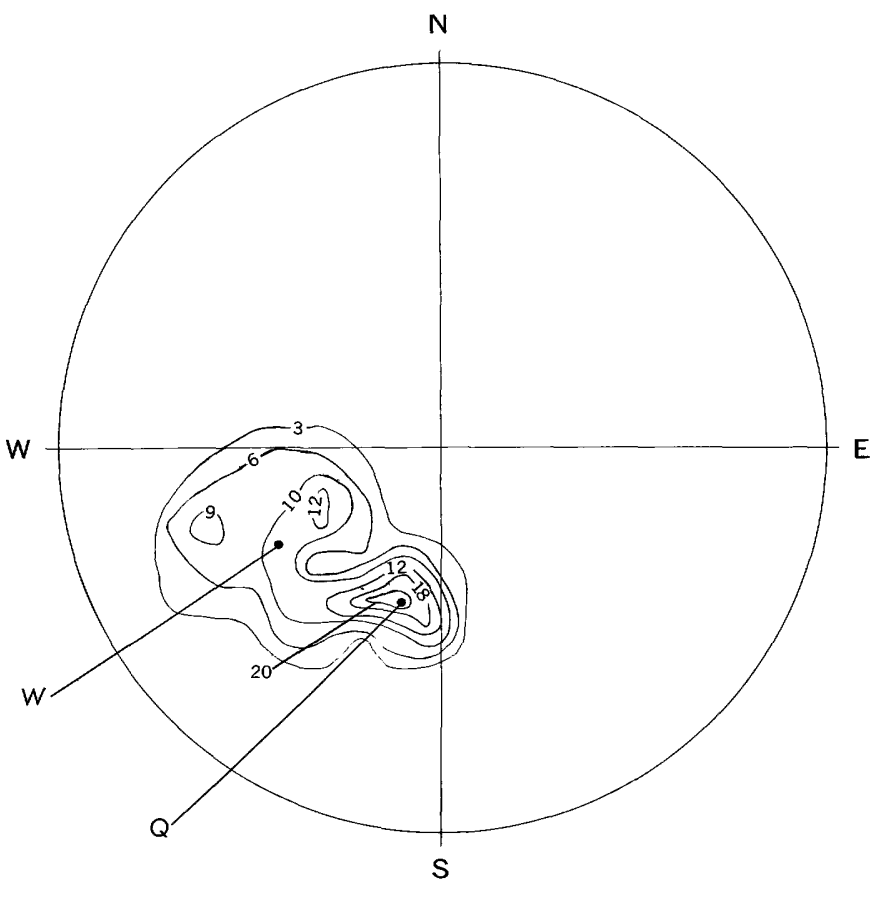

CATACLASTIC SECTOR

50 lineations

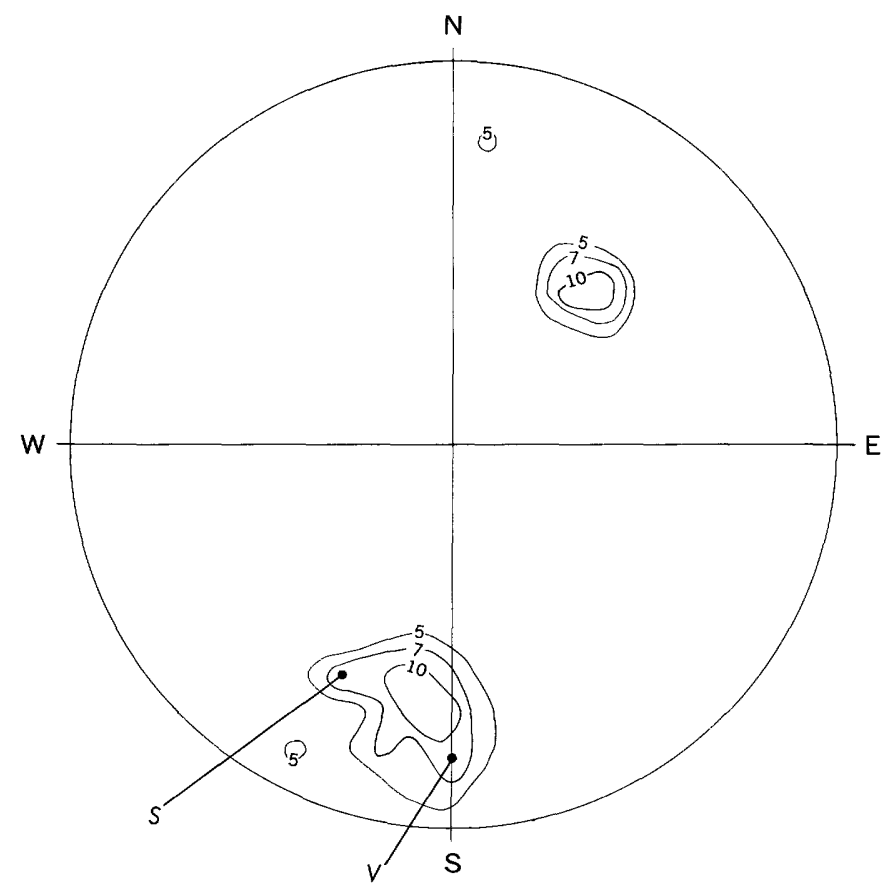

NORTHWEST QUARTZ MONZONITE SECTOR 57 lineations

Figure 9.-Contour diagrams of lineations (lower hemisphere plot). Contoured in percent. Letters indicate concentrations of lineations referred to in the text. 
respectively. The west-southwestward-plunging lineation component $W$, represents southwestward-plunging axes parallel to the Coal Creek syncline.

Mineral lineations plunging south-southwest and nearly south-components $S$ and $V$-appear to have been formed as $a$ lineations on the Coal Creek syncline. These two mineral alinements are contained by the metasedimentary rocks, the quartz monzonite, and Boulder Creek Granite. These data indicate that the igneous rocks were intruded late in the second period of folding.

A third period of deformation formed the cataclastic zone south of the Coal Creek syncline. The foliations formed by this deformation cut metasedimentary layering and early formed foliation in the igneous rocks; the catalastic lineation is represented by component $Q$. This deformation has obliterated all other structures in some area and has modified structures in others. Some minor warping occurred after or late in the cataclastic deformation.

\section{METAMORPHISM RELATED TO STRUCTURAL AND IGNEOUS HISTORY}

The metamorphism of the metasedimentary and metavolcanic (?) rocks is closely related to the structural and intrusive history of the Coal Creek area during the Precambrian Era. The sequence of Precambrian structural and igneous events can be summarized as follows: (1) a relatively early period of plastic folding characterized by widespread pervasive regional metamorphism probably in a deep-seated environment, followed by (2) a second period of deformation, similar to the first, which formed the Coal Creek syncline and was accompanied by intrusion of major Precambrian igneous rocks and additional metamorphism, and (3) a more localized deformation, largely cataclastic in character, that occurred during a third period of Precambrian deformation and formed the Idaho SpringRalston shear zone.

Three periods of metamorphism can be established in the quartzite-schist sequence along the Coal Creek syncline that are probably correlative with the three periods of structural deformation. The first period of metamorphism is represented by the relict staurolite grains enclosed in andalusite grains and by the relict microfolds, which probably formed at the same time as the staurolite, included in andalusite and cordierite grains. The second period of metamorphism is represented by the crystallization of the andalusite, cordierite, and other components of the high-grade metamorphic rocks as they now exist. This metamorphism took place during folding of the Coal Creek syncline and attendant igneous intrusion. The third period of metamorphism is represented by recrystallization during the cataclastic deformation.
Relict minerals have not been recognized in the gneisses of typical Idaho Springs aspect south of the Coal Creek syncline. These gneisses are characterized by sillimanite, however, and rocks of the Coal Creek syncline reached the lower, and locally the higher, sillimanite grade during the second deformation. Nothing indicates that the rocks typical of Idaho Springs underwent higher or more stages of metamorphism than the rocks of the Coal Creek syncline.

Evidence presented indicates that the andalusite is related to the second period of deformation, when the igneous rocks were intruded. Further, there seems to be a relation between the distribution of the aluminum silicate polymorphs andalusite and sillimanite and the quartz monzonite. Andalusite is abundant in the quartzite and schist along Coal Creek where both the quart monzonite and the Boulder Creek Granite are abundant, but no andalusite is found near the Boulder Creek Granite farther south in the Ralston Buttes quadrangle. The mica schist contains andalusite in the Coal Creek area where quartz monzonite is common but contains sillimanite farther southwest in the Ralston Buttes quadrangle, where quartz monzonite is absent.

The occurrence of these polymorphs in the same area may be explained by reference to experimental work with these minerals. Miyashiro (1953, p. 207, fig. 11) figured a proposed stability diagram showing a triple point for the three polymorphs, andalusite, sillimanite, and kyanite, and Thompson (1955, p. 74, 97) derived a similar diagram from thermochemical data. Under conditions near the triple point, rather small fluctuations in pressure and temperature may result in the change from one polymorph to another. Hietanen (1956) interpreted occurrences together of the three polymorphs in cordierite-bearing mica schist in Idaho in the same way. Thompson $(1955$, p. 97$)$ also made it clear that the stability of hydrous aluminum silicates relative to andalusite, sillimanite, and kyanite, depends upon the activity or chemical potential of water as well as upon pressure and temperature. Some of the alteration to muscovite is probably related to fluctuations in the activity or chemical potential of water.

We would suggest that the metamorphic environments that prevailed during syntectonic intrusive activity were sufficiently different from place to place to cause the observed mineralogic differences. The position of andalusite on the stability diagram (Thompson, 1955, fig. 3, p. 97) suggests that metamorphism was characterized by relatively lower pressure or relatively lower temperature along the andalusite-bearing Coal Creek syncline than in the areas where sillimanitic schist formed. 
The abundance of muscovite in the schists of these high-grade metamorphic rocks may seem anomalous, but this may be explained for these rocks that have an excess of $\mathrm{SiO}_{2}$ and $\mathrm{Al}_{2} \mathrm{O}_{3}$ relative to $\mathrm{K}_{2} \mathrm{O}$. In the lower sillimanite zone, andalusite or sillimanite are formed with muscovite. Hemley (1959, p. 268) stated that potassic feldspar is incompatible with andalusite; Fyfe, Turner, and Verhoogen $(1958$, p. 161) stated that potassic feldspar is never associated with any of the three polymorphs of $\mathrm{Al}_{2} \mathrm{SiO}_{5}$ in the lower sillimanite zone. In the higer sillimanite zone where muscovite breaks down to form sillimanite and potassic feldspar in the presence of quartz (Yoder and Eugster, 1955, p. 270), sillimanite and potassic feldspar are compatible; many such mineral suites are reported in the literature. Most of the rocks in the Coal Creek area do not show microcline and sillimanite together and, therefore, are referred to the lower sillimanite zone. In this environment, microcline will not form with the $\mathrm{Al}_{2} \mathrm{SiO}_{5}$ polymorphs, and the $\mathrm{K}_{2} \mathrm{O}$ occurs in muscovite. Where $\mathrm{K}_{2} \mathrm{O}$ content is relatively large, an abundance of muscovite is to be expected.

The late Precambrian cataclastic deformation mechanically reduced the grain size and produced a change in texture of many of the rocks. Some recrystallization accompanied the cataclasis. Late poikilitic muscovite was formed along with a few needles of sillimanite. Potassic feldspar became more perthitic, and all feldspar crystals became less well twinned than they had been. Late microcline filled small fractures. For the most part no retrogressive metamorphism occurred during cataclasis, although additional muscovite seems to have formed, and locally chlorite replaced biotite.

\section{CONCLUSION}

That the quartzite and interlayed schist of the Coal Creek syncline differ from the biotitic gneisses of the Idaho Springs Formation is obvious. Because they are generally finer grained than the gneisses and less contorted and less cut up by pegmatitic stringers, they have been regarded as probably younger than the Idaho Springs Formation. The present study has shown that they are not younger but of the same age as the Idaho Springs type of biotitic gneisses, and they evidently represent a local facies in the sedimentary (and minor volcanic?) rocks that gave rise to the Idaho Springs Formation. They contain inconspicuous interlayers of Idaho Springs type of gneiss, and the gneiss in turn contains interlayers of the quartzite and schist and grades into them-abruptly, to be sure, but definitely.
The quartzite and schist are invaded by all the igneous rocks that invaded the Idaho Springs type of gneisses in this part of the Front Range; they display the same general degree of metamorphism as the Idaho Springs, and they have been subjected to the same deformational history. The quartzite and schist of the Coal Creek syncline must be part of the Idaho Springs Formation.

\section{LITERATURE CITED}

Bastin, E. S., and Hill, J. M., 1917, Economic geology of Gilpin County and adjacent parts of Clear Creek and Boulder Counties, Colorado : U.S. Geol. Survey Prof. Paper 94, 379 p. Cloos, Ernst, 1946, Lineation, a critical review and annotated bibliography : Geol. Soc. America Mem. 18, 122 p.

Fyfe, W. S., Turner, F. J., and Verhoogen, John, 1958, Metamorphic reactions and metamorphic facies: Geol. Soc. America Mem. 73, $259 \mathrm{p}$.

Harrison, J. E., and Moench, R. H., 1961, Joints in Precambrian rocks, Central City-Idaho Springs area, Colorado: U.S. Geol. Survey Prof. Paper 374-B, p. B1-B14.

Harrison, J. E., and Wells, J. D., 1956, Geology and ore deposits of the Freeland-Lamartine district, Clear Creek County, Colorado: U.S. Geol. Survey Bull. 1032-B, p. 33-127.

1959, Geology and ore deposits of the Chicago Creek area, Clear Creek County, Colorado: U.S. Geol. Survey Prof. Paper 319, 92 p.

Heald, M. T., 1950, Structure and petrology of the Lovewell Mountain quadrangle, New Hampshire: Geol. Soc. America Bull., v. 61, no. 1, p. 43-89.

Hemley, J. J., 1959, Some mineralogical equilibria in the system $\mathrm{K}_{2} \mathrm{O}-\mathrm{Al}_{2} \mathrm{O}_{3}-\mathrm{SiO}_{2}-\mathrm{H}_{2} \mathrm{O}$ : Am. Jour. Sci., v. 257, no. 4, p. 241-270.

Hietanen, A. M., 1956, Kyanite, andalusite, and sillimanite in the schist in Boehls Butte quadrangle, Idaho: Am. Mineralogist, v. 41, nos. 1-2, p. 1-27.

Lovering, T. S., 1929, Geologic history of the Front Range, Colorado: Colo. Sci. Soc. Proc., v. 12, no. 4, p. 59-111.

Lovering, T. S., and Goddard, E. N., 1950, Geology and ore deposits of the Front Range, Colorado: U.S. Geol. Survey Prof. Paper 223, 319 p.

Lovering, T. S., and Tweto, Ogden, 1953, Geology and ore deposits of the Boulder County tungsten district, Colorado: U.S. Geol. Survey Prof. Paper 245, 199 p.

Marvine, A. R., 1874, Report on the geology of the region traversed by the Northern or Middle Park division during the working season of 1873, in Hayden, F. V., U.S. Geol. and Geog. Survey Terr. Ann. Rept. for 1873, p. 83-192.

Miyashiro, Akiho, 1953, Calcium-poor garnet in relation to metamorphism: Geochim. et Cosmochim, Acta., v. 4, no. 4, p. 179-208.

Moench, R. H., Harrison, J. E., and Sims, P. K., 1962, Precambrian folding in the Idaho Springs-Central City area, Front Range, Colorado: Geol. Soc. America Bull., v. 73, no. 1, p. 35-58.

Spurr, J. E., Garrey, G. H., and Ball, S. H., 1908, Economic geology of the Georgetown quadrangle (together with the Empire district) Colorado: U.S. Geol. Survey Prof. Paper $63,422 \mathrm{p}$. 
Thompson, J. B., Jr., 1955, The thermodynamic basis for the mineral facies concept: Am. Jour. Sci., v. 253, no. 2, p. 65-103.

1957, The graphical analysis of mineral assemblages in pelitic schists: Am. Mineralogist, v. 42, nos. 11-12, p. 842858.

Tweto, Ogden, and Sims, P. K., 1963, Precambrian ancestry of the Colorado Mineral Belt: Geol. Soc. America Bull., v. 74, p. 991-1014.
Van Hise, C. R., and Leith, C. K., 1909, Pre-Cambrian geology of North America: U.S. Geol. Survey Bull. 360, 939 p.

Yoder, H. S., Jr., and Eugster, H. P., 1955, Synthetic and natural muscovites: Goechim. et Cosmochim. Acta, v. 8, nos. 5-6, p. 225-280.

Young, E. J., and Sims, P. K., 1961, Petrography and origin of xenotime and monazite concentrations, Central City district, Colorado: U.S. Geol. Survey Bull. 1032-F, p. 273-299. 



\section{INDEX}

[Italic page numbers indicate major references]

Acknowledgments and fieldwork.

Alamandine-amphibolite subfacies.

Augen gneiss

Biotite gneiss and mica schist

description

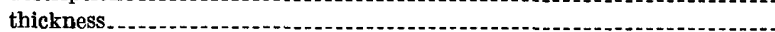

Biotite-quartz-plagioclase, gneiss and mica schist (biotite gneiss and mica schist)

Blackhawk quadrangle

Blue Mountain sector, axes of minor folds

Boulder Creek.

Boulder Creek Granite

(11

composition.

folding.

Calcium silicate rocks with schist in quartzite

Calcium silicate rocks, composition

Cataclastic deformation.

Cataclastic foliation in southwestern part of area

Cataclastic gneiss........................... 7,14

Cataclastic rocks

Coal Creek

Coal Creek area orientation of lineations

Coal Creek Peak

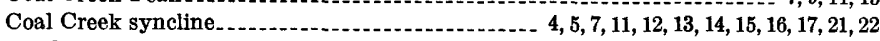
description . -

mineral alinement.

quartzite and schist.

Conclusions

Crescent Mountain sector, axes of minor folds

lineation

Discordant intrusive contacts

Eldorado Springs quadrangle

Fieldwork and acknowledgments

Front Range

$2,4,14,22$

Geologic setting.

Geology, general

Hornblende diorite and hornblendite principal minerals

Hornblende gneiss. description

principal minerals

Idaho Springs Formaticn.

Idaho Springs-Central City area, deformation

$1,2,4,5,14,22$

Idaho Springs-Ralston shear zone

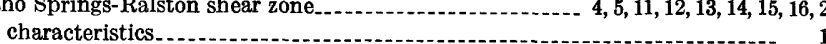

trend.

Igneous rocks.

Laramide orogeny.

Location of area

Mesozoic sedimentary rocks

Metamorphic grade

Metamorphic rocks, Coal Creek area
Metamorphic, metasedimentary, and metavolcanic(?) rocks

Metamorphism related to structural and igneous histor $y$

Metamorphism, three periods.

Metasedimentary and metavolcanic(?) rocks. distribution and stratigraphy.

Mica schist.

6,2

description

principal minerals

Microcline gneiss _._........ 5,13

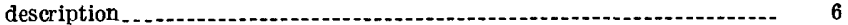

principal minerals

Microcline gneiss and hornblende gneiss...

Microcline-quartz-plagioclase-biotite gneiss (microcil

Microcline-quartz-plagioclase-biotite gneiss and hornblende gneiss (microcline gneiss and hornblende gneiss)

Microcline-sillimanite suite.

Microfolds, relict.

Muscovite-sillimanite mineral suite

Nomenclature of Precambrian rocks.

Nott Creek sector, axes of minor folds

Orientation of lineations, Coal Creek area.

Paleozoic sedimentary rocks.

Pegmatite and aplite.

Pennsylvanian sedimentary rocks.

Phyllite, fine grained schist

Phyllonite, megascopically fine grained rock

Pikes Peak Granite

Polymorphs, occurrence.

Precambrian cataclastic deformation

Precambrian deformation, three periods

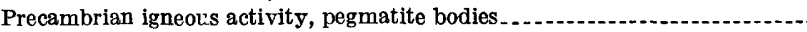

Precambrian rocks, nomenclature.

Precambrian structural and igneous events, summ

South Boulder Creek. 12

Quartzite

composition.

four stratigraphic layers.

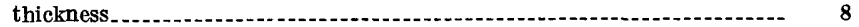

trace minerals. ............... 8

Quartz-schist sequence............ 2, 14

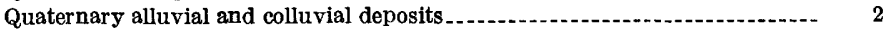

Ralston Buttes quadrangle

$2,6,7,13,21$

Ralston Creek

Schist layers in quartzite

principal minerals

Schist, three major layers

Scope of report.

Sillimanite subfacies

Sillimanite-potassic feldspe

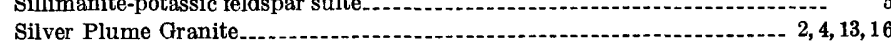

South Boulder Creek

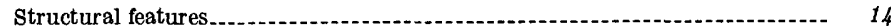

Structural geology of area

Swandyke formation

Three periods of deformation, Precambrian

Ute Creek area

11 